\title{
CoQ10 Deficiency May Indicate Mitochondrial Dysfunction in Cr(VI) Toxicity
}

\author{
Xiali Zhong ${ }^{1,2}$, Xing Yi ${ }^{1}$, Rita de Cássia da Silveira e Sá ${ }^{3}$, Yujing Zhang ${ }^{1}$, Kaihua Liu ${ }^{1}$, \\ Fang Xiao ${ }^{1}$ and Caigao Zhong ${ }^{1, *}$ \\ 1 Department of Health Toxicology, School of Public Health, Central South University, Changsha 410008, \\ China; xializhong87@sina.com (X.Z.); yistar@163.com (X.Y.); zhangyujing24@163.com (Y.Z.); \\ lecapher@gmail.com (K.L.); fangxiao@csu.edu.cn (F.X.) \\ 2 Department of Environmental Health Science, Bloomberg School of Public Health, \\ Johns Hopkins University, Baltimore, MD 21205, USA \\ 3 Department of Physiology and Pathology, Health Sciences Center, Federal University of Paraíba, \\ 58059-900 João Pessoa, Brazil; ritacassia.sa@bol.com.br \\ * Correspondence: caigaozhong@gmail.com; Tel.: +86-731-8480-5461
}

Academic Editors: Ashis Basu and Takehiko Nohmi

Received: 11 February 2017; Accepted: 7 April 2017; Published: 24 April 2017

\begin{abstract}
To investigate the toxic mechanism of hexavalent chromium $\mathrm{Cr}(\mathrm{VI})$ and search for an antidote for $\mathrm{Cr}(\mathrm{VI})$-induced cytotoxicity, a study of mitochondrial dysfunction induced by $\mathrm{Cr}(\mathrm{VI})$ and cell survival by recovering mitochondrial function was performed. In the present study, we found that the gene expression of electron transfer flavoprotein dehydrogenase (ETFDH) was strongly downregulated by $\mathrm{Cr}(\mathrm{VI})$ exposure. The levels of coenzyme 10 (CoQ10) and mitochondrial biogenesis presented by mitochondrial mass and mitochondrial DNA copy number were also significantly reduced after $\mathrm{Cr}(\mathrm{VI})$ exposure. The subsequent, $\mathrm{Cr}(\mathrm{VI})$-induced mitochondrial damage and apoptosis were characterized by reactive oxygen species (ROS) accumulation, caspase-3 and caspase-9 activation, decreased superoxide dismutase (SOD) and ATP production, increased methane dicarboxylic aldehyde (MDA) content, mitochondrial membrane depolarization and mitochondrial permeability transition pore (MPTP) opening, increased $\mathrm{Ca}^{2+}$ levels, Cyt c release, decreased Bcl-2 expression, and significantly elevated Bax expression. The $\mathrm{Cr}(\mathrm{VI})$-induced deleterious changes were attenuated by pretreatment with CoQ10 in L-02 hepatocytes. These data suggest that $\mathrm{Cr}(\mathrm{VI})$ induces CoQ10 deficiency in L-02 hepatocytes, indicating that this deficiency may be a biomarker of mitochondrial dysfunction in $\mathrm{Cr}(\mathrm{VI})$ poisoning and that exogenous administration of CoQ10 may restore mitochondrial function and protect the liver from $\mathrm{Cr}(\mathrm{VI})$ exposure.
\end{abstract}

Keywords: hexavalent chromium $\mathrm{Cr}(\mathrm{VI})$; coenzyme Q10; reactive oxygen species (ROS); mitochondrial membrane potential (MMP); L-02 hepatocytes; apoptosis

\section{Introduction}

Chromium ( $\mathrm{Cr}$ ) and its compounds have become a serious public health issue, causing environmental pollution $[1,2]$ and threatening human health. The health hazards associated with exposure to $\mathrm{Cr}$ are dependent on its oxidation state [3,4], with hexavalent chromium $\mathrm{Cr}(\mathrm{VI})$ being the most toxic component. Throughout the world, human exposure occurs mainly via industrial uses, such as leather tanning and steel manufacturing, as well as in food additives and tobacco $[5,6]$. Another source of contact is drinking water contaminated with $\mathrm{Cr}(\mathrm{VI})$. In vivo and in vitro studies have demonstrated that $\mathrm{Cr}(\mathrm{VI})$ can cause a wide range of toxic effects, including hepatotoxicity, in animals and humans [1-4]. It has been reported that the liver shows the highest accumulation following oral exposure to $\mathrm{Cr}(\mathrm{VI})$ [7-9]. The liver is the primary organ involved in xenobiotic metabolism 
and, for this reason, is particularly susceptible to injury. However, the liver as a target organ for $\mathrm{Cr}(\mathrm{VI})$ after oral exposure in humans remains controversial. For instance, Proctor et al. reported that $\mathrm{Cr}(\mathrm{VI})$ is not carcinogenic to humans via the oral route of exposure at permissible drinking water concentrations [10]. Several other studies have suggested that $\mathrm{Cr}(\mathrm{VI})$ could induce liver injury $[1,3,11]$ and may cause primary cancer or increase the risk of liver cancer [12-14]. The increasing incidence of $\mathrm{Cr}(\mathrm{VI})$-induced hepatotoxicity has emphasized the importance of elucidating the intoxication mechanism and identifying useful antidotes for $\mathrm{Cr}(\mathrm{VI})$ toxic effects on the liver.

$\mathrm{Cr}(\mathrm{VI})$ can easily enter cells through anion channels, and, once inside, it is reduced to its intermediate metabolites, $\mathrm{Cr}(\mathrm{IV}), \mathrm{Cr}(\mathrm{V})$, and the more stable form $\mathrm{Cr}(\mathrm{III})$, by enzymatic and non-enzymatic reductants [15]. Reactive oxygen species (ROS) are generated in the oxidation-reduction process and play a critical role in the mechanism of $\mathrm{Cr}(\mathrm{VI})$-induced cytotoxicity. ROS accumulation, for instance, is known to cause the collapse of mitochondrial membrane potential and the opening of the mitochondrial permeability transition pore (MPTP) [16]. $\mathrm{Cr}(\mathrm{VI})$ induces cell apoptosis through intrinsic and extrinsic pathways involving the release of cytochrome c (Cyt c) from the mitochondrial intermembrane space. The release of Cyt $\mathrm{c}$ from the mitochondrial intermembrane space is regulated by B-cell lymphoma-2 (Bcl-2) family proteins, including anti-apoptotic (such as Bcl-2 and Bcl-xl) and pro-apoptotic proteins (such as Bcl-xs, Bax, and Bid) [17]. It has been postulated that the ratio of anti- and pro-apoptotic Bcl proteins regulates the function of MPTP within the mitochondria. $\mathrm{Cr}(\mathrm{VI})$-induced ROS accumulation might cause an imbalance in Bcl-2 family proteins, swelling of the mitochondrial membrane, opening of the MPTP, release of Cyt $\mathrm{c}$ into the cytoplasm, and activation of caspase-9 and $-3[17,18]$, which would eventually trigger cell apoptosis.

Coenzyme $Q(C o Q 10)$ is an essential endogenous molecule in cell respiration and metabolism. It functions as a mitochondrial antioxidant, inhibiting lipid peroxidation and scavenging free radicals, as well as maintaining genome stability [19]. Moreover, CoQ10 possesses an independent anti-apoptosis function that regulates MPTP [20]. CoQ10 biosynthesis occurs in the mitochondrial matrix through the mevalonate pathway [21]. Evidence suggests that mutations in the genes involved in the biosynthesis of CoQ10 could cause primary and secondary CoQ10 deficiencies. They have also been linked to various clinical mitochondrial diseases [22,23]. CoQ10 deficiency could disturb mitochondrial bioenergetics and oxidative stress, as demonstrated by decreased ATP generation, increased ROS production, and cell death [24,25]. In general, secondary CoQ10 deficiency may be induced by dietary insufficiency or exposure to certain xenobiotics [26,27]. Several studies have shown that CoQ10 is susceptible to environmental toxins, which cause CoQ10 deficiency at both the cellular and in vivo levels [28,29]. Considering the pivotal role played by CoQ10 in mitochondrial function, this study aimed to investigate whether $\mathrm{Cr}(\mathrm{VI})$ can induce changes in the level of CoQ10, and whether CoQ10 treatment is effective against $\mathrm{Cr}(\mathrm{VI})$-induced hepatotoxicity.

\section{Results}

\subsection{Effect of Coenzyme Q10 and Cr(VI) on L-02 Hepatocyte Viability}

To assay the changes in cell viability after exposure to $\mathrm{Cr}(\mathrm{VI})$, we evaluated the dose effects of $\mathrm{Cr}(\mathrm{VI})$ on cultured L-02 hepatocytes with or without CoQ10 pretreatment. It was observed that increasing $\mathrm{Cr}(\mathrm{VI})$ concentrations of $0.5,1,2,4$, and $8 \mu \mathrm{M}$ significantly decreased cell viability $(p<0.05)$, as shown in Figure 1A. Treatment with CoQ10 at $0-5 \mu \mathrm{M}$ increased cell viability, although not at a statistically significant level $(p>0.05)$. In contrast, treatment with concentrations of 5-20 $\mu \mathrm{M}$ CoQ10 significantly decreased cell viability $(p<0.05)$, as shown in Figure 1B.

\section{2. $\mathrm{Cr}(V I)$ Decreases CoQ10 Content in L-02 Hepatocytes}

The assays of CoQ10 level showed that $\mathrm{Cr}(\mathrm{VI})$ decreased the CoQ10 concentration in the mitochondria of L-02 hepatocytes when compared with the control group $(p<0.05)$. Pretreatment 
with CoQ10 restored the level of CoQ10 compared with the $2 \mu \mathrm{M} \mathrm{Cr}(\mathrm{VI})$ treatment group $(p<0.05)$, as shown in Figure 1C.

A

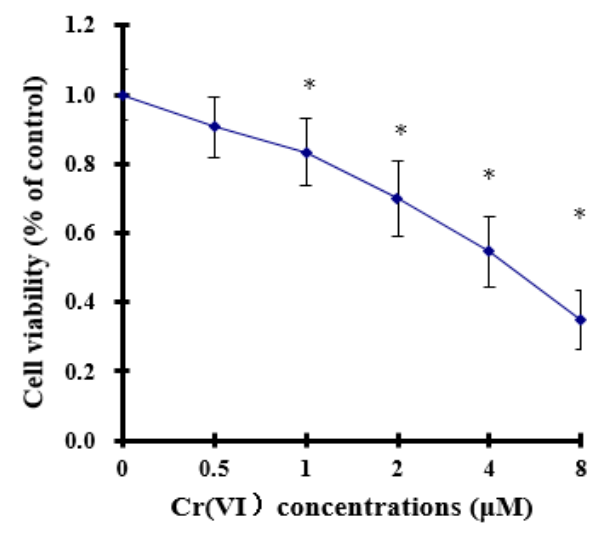

B

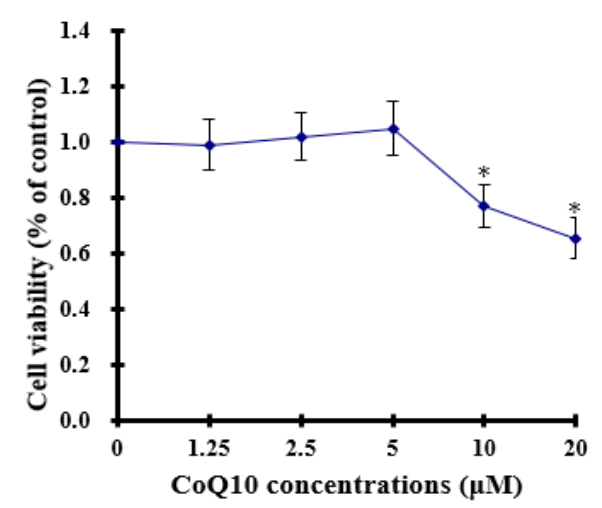

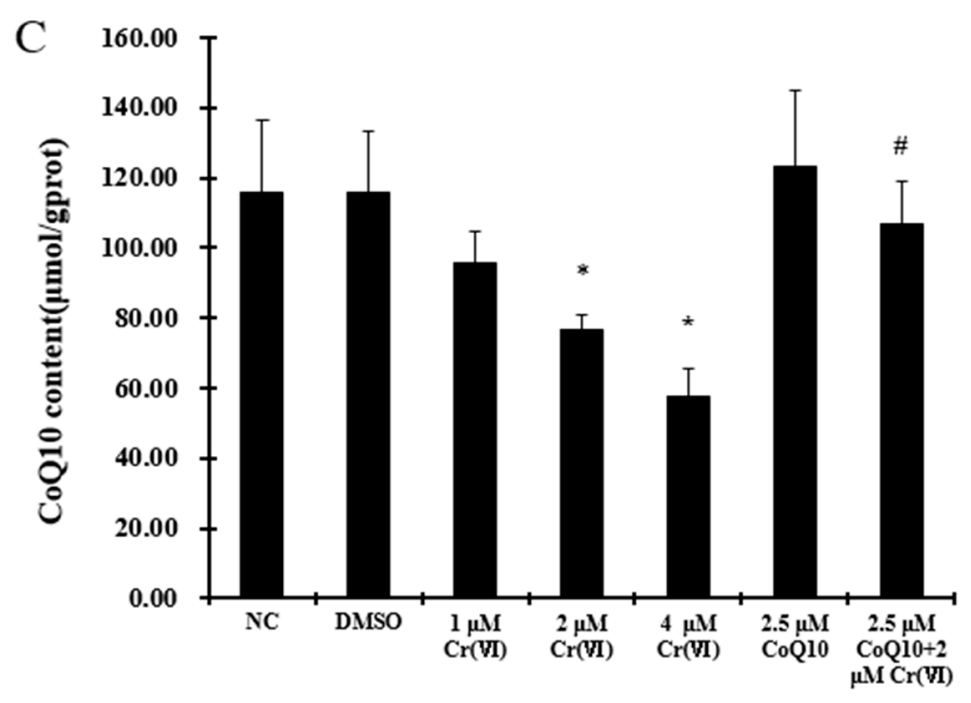

Figure 1. (A) Effect of different doses of $\mathrm{Cr}(\mathrm{VI})$ exposure on L-02 hepatocyte viability. Cells were cultured with different concentrations of $\mathrm{Cr}(\mathrm{VI})$, and the cell viability was determined by the 3-(4,5-dimethylthiazol-2-yl)-2,5-diphenyltetrazolium bromide (MTT) assay as described previously; (B) Effect of different doses of CoQ10 exposure on L-02 hepatocyte viability; (C) The CoQ10 content in the mitochondria of L-02 hepatocytes treated with $\mathrm{CoQ} 10$ and $\mathrm{Cr}(\mathrm{VI})$. The data were presented as mean $\pm \mathrm{SD}(n=6) .{ }^{*} p<0.05$ compared with the control group; $\# p<0.05$ compared with the $2 \mu \mathrm{M}$ $\mathrm{Cr}(\mathrm{VI})$ treatment group.

\subsection{Effect of Cr(VI) on the Expression of Genes Involved in the CoQ10 Synthesis Pathway}

Because $\mathrm{Cr}(\mathrm{VI})$ treatment decreased the level of CoQ10, and to understand the mechanism of CoQ10 deficiency, we analyzed the expression of genes involved directly or indirectly in the CoQ10 synthesis pathway. As shown in Table 1, electron transfer flavoprotein dehydrogenase (ETFDH) was the gene most strongly downregulated by $\mathrm{Cr}(\mathrm{VI})(\log 2$ (Ratio) $=-1.41) . P D S S 2, C O Q 5$, and COQ9 were also downregulated by $\mathrm{Cr}(\mathrm{VI})$, but the fold changes were less than $2(\log 2$ (Ratio) $=-0.92,-0.99$, and -0.94 , respectively). Interestingly, aarF domain-containing kinase 3 (ADCK3) was upregulated after exposure to $\mathrm{Cr}(\mathrm{VI})(\log 2($ Ratio $)=0.97)$. No significant changes were observed in the other genes. These results indicated that $\mathrm{Cr}(\mathrm{VI})$ affected the expression of genes directly or indirectly involved in the CoQ10 synthesis pathway to cause CoQ10 deficiency. 
Table 1. Effect of $\mathrm{Cr}(\mathrm{VI})$ on the expression of genes involved in the CoQ10 biosynthesis pathway in L-02 hepatocytes.

\begin{tabular}{cccc}
\hline Gene Name & Description & log2(Ratio) & $p$-Values \\
\hline PDSS1 & prenyl (decaprenyl) diphosphate synthase, subunit 1 & 0.079217 & 0.728622 \\
PDSS2 & prenyl (decaprenyl) diphosphate synthase, subunit 2 & -0.917213 & $2.86 \times 10^{-5}$ \\
COQ2 & coenzyme Q2 homolog, prenyltransferase & -0.136864 & 0.434046 \\
COQ3 & coenzyme Q3 homolog, methyltransferase & -0.443767 & 0.002707 \\
COQ4 & coenzyme Q4 homolog & -0.646236 & 0.004524 \\
COQ5 & coenzyme Q5 homolog, methyltransferase & -0.986167 & $4.4 \times 10^{-8}$ \\
COQ6 & coenzyme Q6 homolog, monooxygenase & -0.185303 & 0.267227 \\
COQ7 & coenzyme Q7 homolog, ubiquinone & -0.308896 & 0.011926 \\
COQ7 & coenzyme Q7 homolog, ubiquinone & -0.528129 & 0.115161 \\
ADCK3 & aarF domain containing kinase 3 & 0.970573 & $6.12 \times 10^{-9}$ \\
ADCK4 & aarF domain containing kinase 4 & $\mathrm{NA}$ & $\mathrm{NA}$ \\
COQ9 & coenzyme Q9 homolog & -0.936477 & $3.1 \times 10^{-18}$ \\
COQ10A & coenzyme Q10 homolog A & 0.239029 & 0.045092 \\
COQ10B & coenzyme Q10 homolog B & 0.59875 & 0.000958 \\
APTX & aprataxin & -0.648958 & 0.003698 \\
ETFDH & electron-transferring-flavoprotein dehydrogenase & -1.412843 & $4.43 \times 10^{-7}$ \\
BRAF & B-Raf proto-oncogene, serine/threonine kinase & -0.837738 & 0.008798 \\
PMVK & phosphomevalonate kinase & -0.146285 & 0.455768 \\
$M V D$ & mevalonate (diphospho) decarboxylase & 0.842443 & 0.01009 \\
$M V K$ & mevalonate kinase & 0.612375 & 0.000892 \\
\hline
\end{tabular}

Two-fold change indicates $\log 2$ (Ratio) $\geq 1.0$ or $\log 2$ (Ratio) $\leq-1 ; \log 2$ (Ratio) = "NA" indicates that the difference in intensity between the two samples was $\geq 1000.0, n=3$.

\subsection{Oxidative Damage Induced by $\mathrm{Cr}(\mathrm{VI})$ Is Reduced by $\mathrm{CoQ} 10$}

We measured ROS production using dihydroethidine (DHE) and CellROX ${ }^{\circledR}$ Green Reagent, which detect superoxide and ROS, respectively. $\mathrm{Cr}(\mathrm{VI})$ significantly enhanced $\mathrm{ROS}$ and $\mathrm{O}_{2}{ }^{-}$generation compared with the control group $(p<0.05)$. Pretreatment with $2.5 \mu \mathrm{M}$ CoQ10 prevented $\mathrm{Cr}(\mathrm{VI})$-induced ROS accumulation and excessive $\mathrm{O}_{2}{ }^{-}$, as shown in Figure 2A,B. The levels of ROS in the CoQ10-treated group did not significantly change in comparison with those of the normal control group $(p>0.05)$. SOD is an enzyme that plays an important role in the protection of the cell membrane against oxidative stress. It can catalyze the dismutation of $\mathrm{O}_{2}{ }^{-}$to $\mathrm{O}_{2}$ and to the less reactive species $\mathrm{H}_{2} \mathrm{O}_{2}$. Treatment with $\mathrm{Cr}(\mathrm{VI})$ caused a significant decrease in SOD levels when compared to control values. No significant difference in SOD activity was observed between the $\mathrm{Cr}(\mathrm{VI})$ group pretreated with CoQ10 and the control group $(p<0.05)$, as shown in Figure 2C. In addition, CoQ10 effectively restored the SOD level to protect hepatocytes against oxidative damage induced by $\mathrm{Cr}(\mathrm{VI})$. MDA was evaluated as an indicator of hepatocyte lipid peroxidation. $\mathrm{Cr}(\mathrm{VI})$ significantly increased MDA levels compared with the control group $(p<0.05)$, and pretreatment with CoQ10 markedly reduced the level of $\mathrm{Cr}(\mathrm{VI})$-induced MDA $(p<0.05)$ (Figure 2C).

A

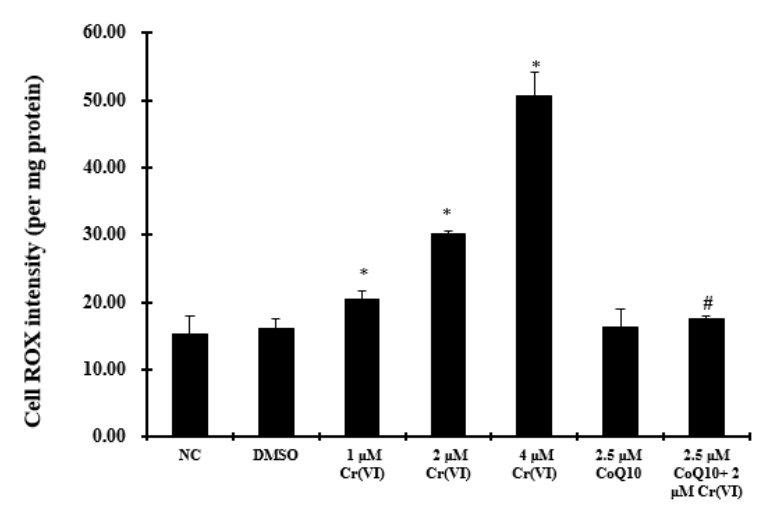

Figure 2. Cont. 

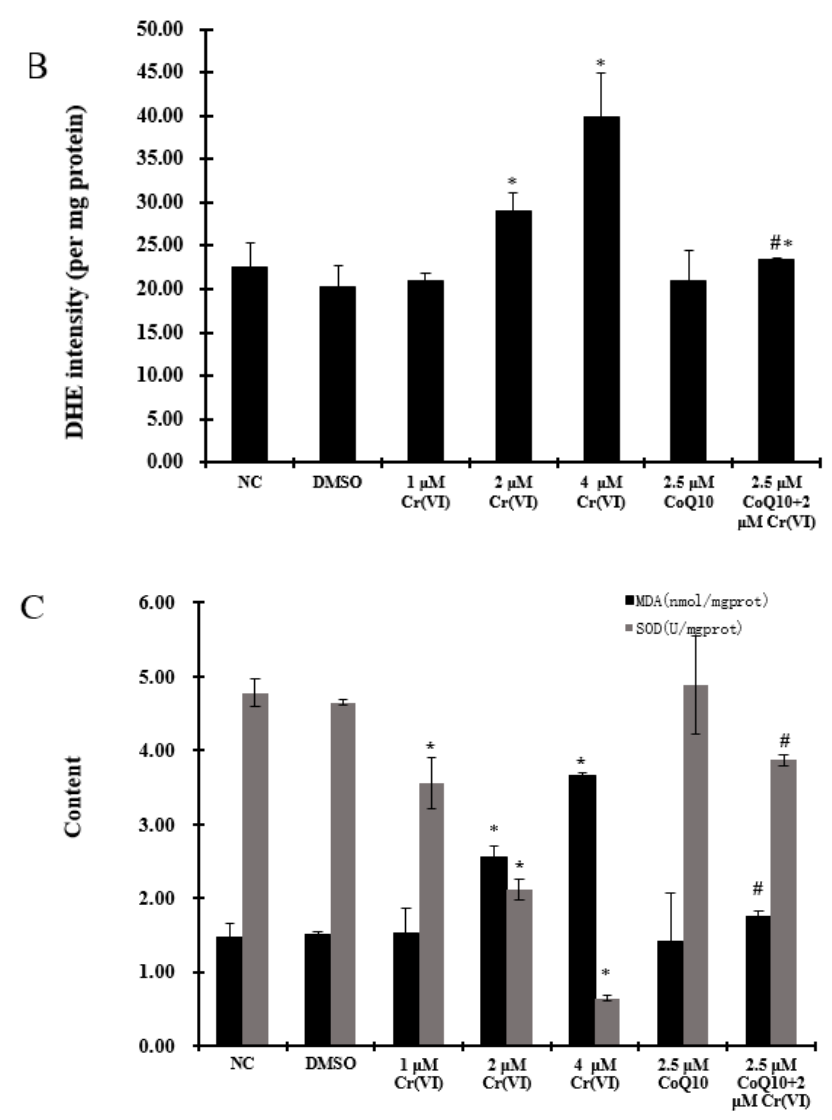

D
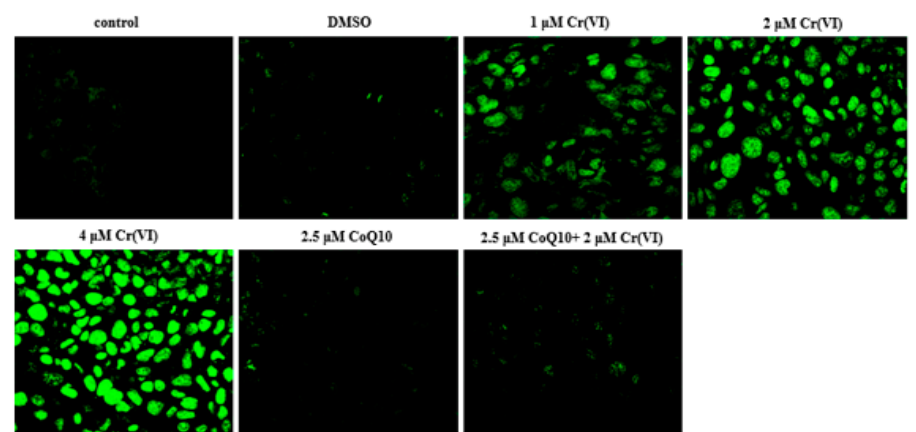

$2.5 \mu \mathrm{M} \mathrm{CoQ} 10$

$2.5 \mu \mathrm{M} \mathrm{C} \circ \mathrm{Q} 10+2 \mu \mathrm{M} \mathrm{Cr}(\mathrm{VI})$

Figure 2. CoQ10 attenuates oxidative damage induced by $\mathrm{Cr}(\mathrm{VI})$. (A) Quantification of ROS levels. Effect of CoQ10 on Cr(VI)-induced ROS accumulation in L-02 hepatocytes and quantitation by fluorescence spectrophotometry; (B) After L-02 hepatocytes were treated with $\mathrm{Cr}(\mathrm{VI})(0 \sim 4 \mu \mathrm{M})$ for $24 \mathrm{~h}$, with or without CoQ10 pretreatment for $2 \mathrm{~h}, \mathrm{O}_{2}{ }^{-}$generation was detected with dihydroethidium; (C) CoQ10 reduced the oxidative damage induced by $\mathrm{Cr}(\mathrm{VI})$. The cells were treated with $\mathrm{Cr}(\mathrm{VI})$ $(0 \sim 4 \mu \mathrm{M})$ for $24 \mathrm{~h}$, with or without CoQ10 pretreatment, and MDA was detected by the MDA detection kit as the end product of lipid oxidation. SOD was measured using the total superoxide dismutase activity assay, which involves the inhibition of superoxide-induced chromogen chemiluminescence by SOD; (D) Effect of CoQ10 on Cr(VI)-induced ROS accumulation. The cells were incubated with $5 \mu \mathrm{M}$ of CellROX ${ }^{\circledR}$ Green Reagent for $30 \mathrm{~min}$ and observed under a confocal microscope using a $40 \times$ objective. Brighter green fluorescence indicated greater ROS accumulation. The data are presented as mean $\pm \mathrm{SD}(n=6)$. ${ }^{*} p<0.05$ compared with the control group; $\# p<0.05$ compared with the $2 \mu \mathrm{M}$ $\mathrm{Cr}(\mathrm{VI})$ treatment group. 


\subsection{Induction of Mitochondrial Loss by Cr(VI) Can Be Counteracted by Supplementation with CoQ10}

Mitochondrial loss was reflected by a decrease in the mitochondrial mass and mtDNA. We examined the mitochondrial mass using the 10- $\mathrm{N}$-nonyl acridine orange (NAO) fluorescence intensity, which was lower in the different $\mathrm{Cr}(\mathrm{VI})$ concentration groups than in the control group. CoQ10 maintained the mitochondrial mass at a normal level against $\mathrm{Cr}(\mathrm{VI})$ exposure (Figure 3A). In addition, $\mathrm{Cr}(\mathrm{VI})$ treatment markedly reduced the mtDNA copy number, and CoQ10 preserved the mtDNA copy number (Figure 3B).

A

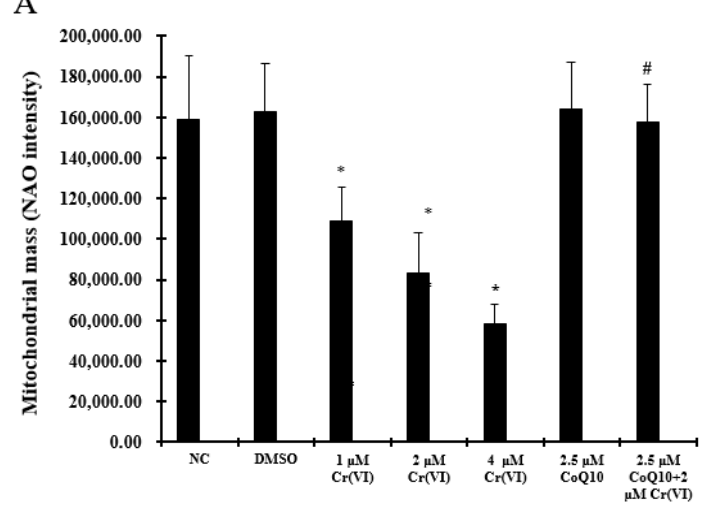

B

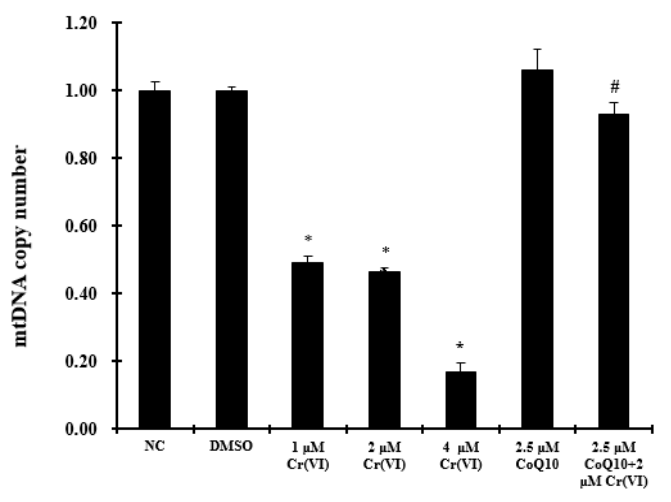

Figure 3. $\mathrm{Cr}(\mathrm{VI})$ triggers significant mitochondrial biogenesis loss. (A) NAO staining was used to analyze the mitochondrial mass using a microplate reader; (B) quantitative real-time PCR analysis was applied to detect the mtDNA copy number. The data are presented as mean $\pm \operatorname{SD}(n=6) .{ }^{*} p<0.05$ compared with the control group; \# $p<0.05$ compared with the $2 \mu \mathrm{M} \mathrm{Cr}(\mathrm{VI})$ treatment group.

2.6. Cr(VI) Induces Mitochondrial Depolarization, MPTP Opening, $\mathrm{Ca}^{2+}$ Overload, and Decreased ATP Levels, and These Outcomes Are Attenuated by CoQ10

The effect of $\mathrm{Cr}(\mathrm{VI})$ on the mitochondrial membrane potential (MMP) was quantified by the uptake of JC-1, as illustrated in Figure 4A. The shift in the membrane potential was observed as the disappearance of fluorescent red/green-stained mitochondria, showing a large negative MMP, and as the increase in fluorescent green-stained mitochondria, indicating the loss of MMP. With increasing $\mathrm{Cr}(\mathrm{VI})$ concentrations, MMP significantly decreased as compared to the normal controls $(p<0.05)$, indicating mitochondrial membrane depolarization. Pretreatment with CoQ10 relieved $\mathrm{Cr}(\mathrm{VI})$-induced mitochondrial membrane depolarization. To directly assess MPTP opening, the calcein-AM-cobalt assay was performed in L-02 hepatocytes. The inner mitochondrial membrane permeability was significantly increased in response to $\mathrm{Cr}(\mathrm{VI})$ stimuli in a concentration-dependent manner. The degree of MPTP opening in cells after co-incubation with $2 \mu \mathrm{M} \mathrm{Cr}(\mathrm{VI})$ and $2.5 \mu \mathrm{M}$ CoQ10 was significantly decreased compared with cells incubated with $2 \mu \mathrm{M} \mathrm{Cr}(\mathrm{VI})$ alone (Figure 4B). MPTP opening is a $\mathrm{Ca}^{2+}$-dependent event; hence, to assess the $\mathrm{Ca}^{2+}$ concentration in L-02 hepatocytes, as shown in Figure 4C, the cells were incubated with the Flo-3M probe to detect the intercellular $\mathrm{Ca}^{2+}$ concentration. $\mathrm{Cr}(\mathrm{VI})$ caused a statistically significant $\mathrm{Ca}^{2+}$ concentration-dependent increase $(p<0.05)$, while pretreatment with CoQ10 significantly attenuated $\mathrm{Ca}^{2+}$ overload when compared with treatment with $2 \mu \mathrm{M} \mathrm{Cr}(\mathrm{VI})$ alone $(p<0.05)$. These results suggest that $\mathrm{CoQ} 10$ suppressed $\mathrm{Ca}^{2+}$ overload and maintained a suitable degree of MPTP opening. Apoptosis induced by toxicants is an energy-consuming process and thus is accompanied by a massive decrease in cellular ATP production. To examine the effects of $\mathrm{Cr}(\mathrm{VI})$ on mitochondrial ATP production, L-02 hepatocytes were treated with 1,2 , or $4 \mu \mathrm{M} \mathrm{Cr}(\mathrm{VI})$ for $24 \mathrm{~h}$ or pretreated with $2.5 \mu \mathrm{M}$ CoQ10 for $30 \mathrm{~min}$, followed by the addition of $2 \mu \mathrm{M} \mathrm{Cr}(\mathrm{VI})$. ATP levels were then measured colorimetrically. As shown in Figure 4D, $\mathrm{Cr}(\mathrm{VI})$ induced a statistically significant and concentration-dependent decrease in ATP in L-02 hepatocytes $(p<0.05)$. Pretreatment with CoQ10 significantly decreased the $\mathrm{Cr}(\mathrm{VI})$-induced decrease in ATP $(p<0.05)$. 
A

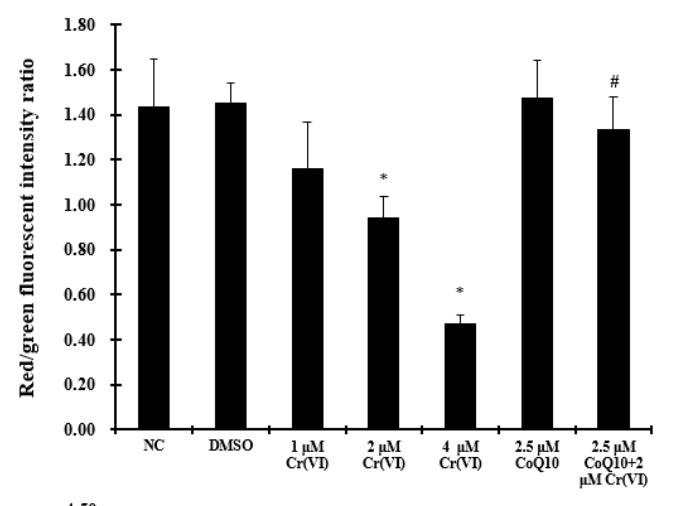

B

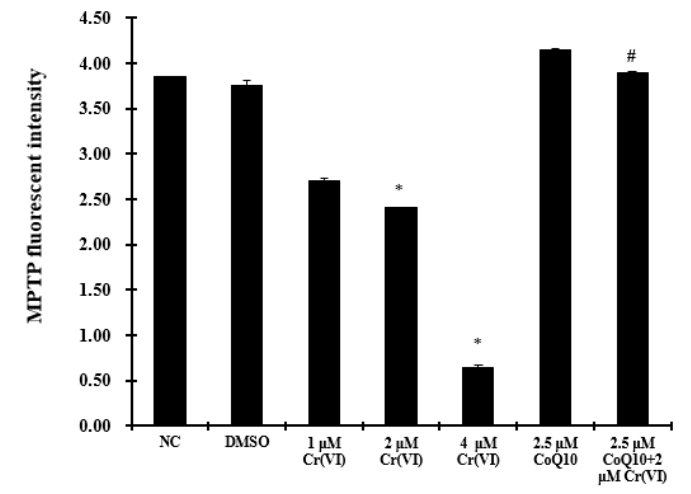

C

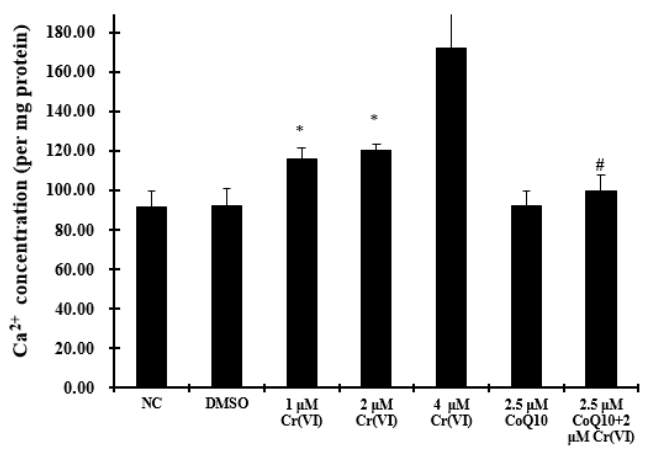

$\mathrm{D}$

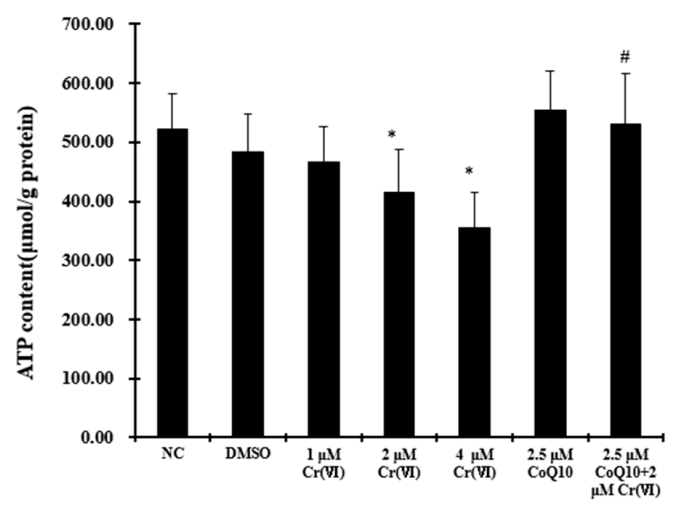

Figure 4. $\mathrm{Cr}(\mathrm{VI})$ induces mitochondrial depolarization, MPTP opening, $\mathrm{Ca}^{2+}$ overload, and ATP level decrease, and these outcomes are attenuated by CoQ10. (A) Effect of CoQ10 on Cr(VI)-increased mitochondrial membrane potential in L-02 hepatocytes. The mitochondrial membrane potential was examined by JC-1 staining; (B) The activity of MPTP was detected using the calcein-AM-cobalt assay; (C) the $\mathrm{Ca}^{2+}$ concentration was measured with Flo-3M by fluorescence spectrophotometry; (D) cells were treated with $\mathrm{Cr}(\mathrm{VI})(0-4 \mu \mathrm{M})$ for $24 \mathrm{~h}$, with or without CoQ10 pretreatment for $2 \mathrm{~h}$, and the ATP levels in L-02 hepatocytes were assessed. The data are presented as mean $\pm \operatorname{SD}(n=6)$. ${ }^{*} p<0.05$ compared with the control group; \# $p<0.05$ compared with the $2 \mu \mathrm{M} \mathrm{Cr}(\mathrm{VI})$ treatment group. 
2.7. Cr(VI) Induces Cyt c Release, Caspase-3 and Caspase-9 Activation, and Unbalanced Bcl-2/Bax Expression in Response to Apoptotic Stimuli, and CoQ10 Counteracts These Outcomes

Cyt c, caspase-3 and caspase-9 activities were analyzed as indexes of apoptosis execution via the intrinsic (mitochondrion-dependent) pathway. Figure 5 shows the release of Cyt c into the cytoplasm. At $24 \mathrm{~h}$ after application of $\mathrm{Cr}(\mathrm{VI})$, cytoplasmic Cyt c levels were markedly increased but remained substantially unaffected if treatment was preceded by CoQ10 administration. Similarly, Figure 6A,B show that caspase- 3 and caspase- 9 activities were enhanced at $24 \mathrm{~h}$ after $\mathrm{Cr}(\mathrm{VI})$ exposure. The enhancement was dramatically lower when $\mathrm{Cr}(\mathrm{VI})$ exposure was preceded by CoQ10 administration. CoQ10 had the ability to prevent Cyt c release, and caspase-3 and caspase- 9 activation in response to $\mathrm{Cr}(\mathrm{VI})$ exposure, three events that are triggered by MPTP opening. CoQ10 inhibited apoptosis by directly maintaining MPTP in the closed conformation. Additionally, the process of apoptosis is regulated by the $\mathrm{Bcl}-2$ family of proteins, which includes anti-apoptotic and pro-apoptotic proteins. As shown in Figure 6C,D, 24-h exposure to different concentrations of $\mathrm{Cr}(\mathrm{VI})$ induced significant concentration-dependent inhibition of Bcl-2 and induction of Bax. Pretreatment with $2.5 \mu \mathrm{M}$ CoQ10 restored Bcl-2 expression and decreased Bax expression compared with treatment with $2 \mu \mathrm{M}$ $\mathrm{Cr}(\mathrm{VI})$ alone.

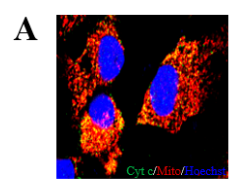

contro

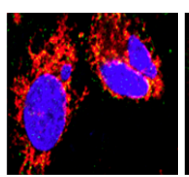

DMso

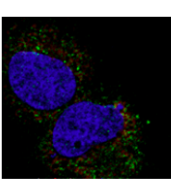

$1 \mu \mathrm{M} \mathrm{Cr}(\mathrm{VI})$

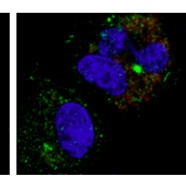

$2 \mu \mathrm{M} \mathbf{C r}(\mathrm{VI})$

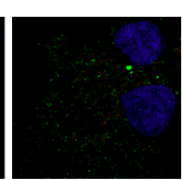

$4 \mu \mathrm{M} \mathrm{Cr}(\mathrm{VI})$

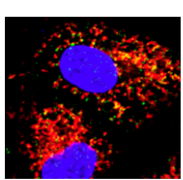

$2.5 \mu \mathrm{M}$ CoQ10

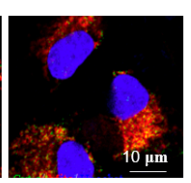

$2.5 \mu \mathrm{M} \operatorname{CoQ} 10+2 \mu \mathrm{M} \mathrm{Cr}(\mathrm{VI})$

$\mathbf{B}$

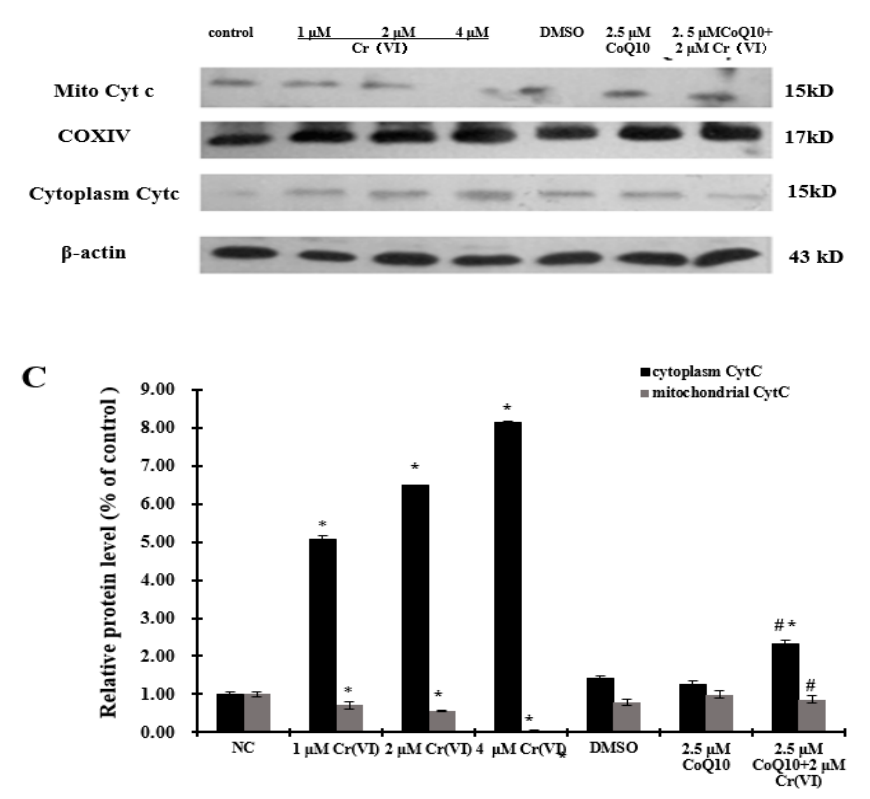

Figure 5. $\mathrm{Cr}(\mathrm{VI})$ induces cytochrome c release from the mitochondria to the cytoplasm. (A) Merged images of the mitochondria (red), Cyt c (green) and nucleus (blue) after exposure to Cr(VI) for $24 \mathrm{~h}$ in L-02 hepatocytes. Cyt c (green) and mitochondria (red) localization (yellow) indicates that Cyt c is still inside mitochondria. The separation of Cyt $\mathrm{c}$ and mitochondria suggests that $\mathrm{Cyt} \mathrm{c}$ is no longer within the mitochondria and has been released into the cytoplasm, scale bar: $10 \mu \mathrm{m}$; (B) CoQ10 prevents Cyt c release to the cytoplasm; Cyt c protein expression was measured by Western blotting. COXIV and $\beta$-actin were used as loading controls; (C) The relative protein levels were calculated by Image J software. Experiments were repeated three times and showed similar results. 
A
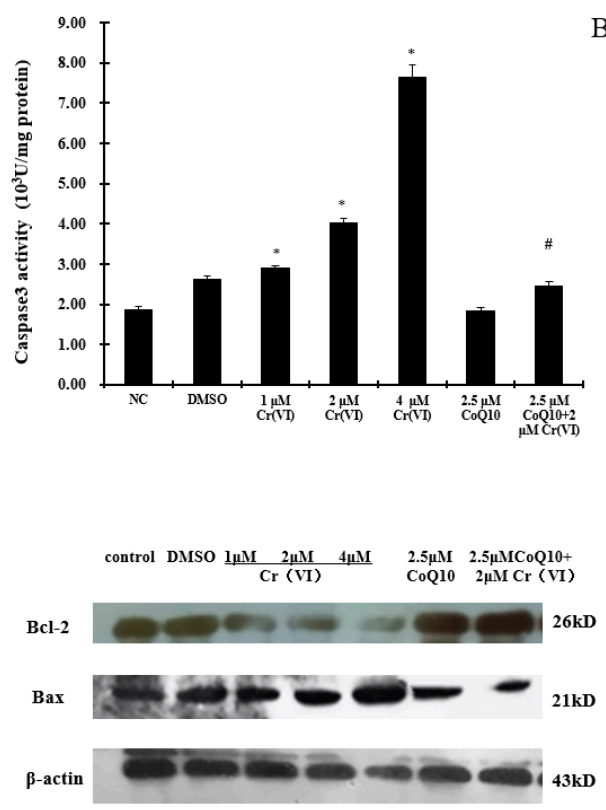

B

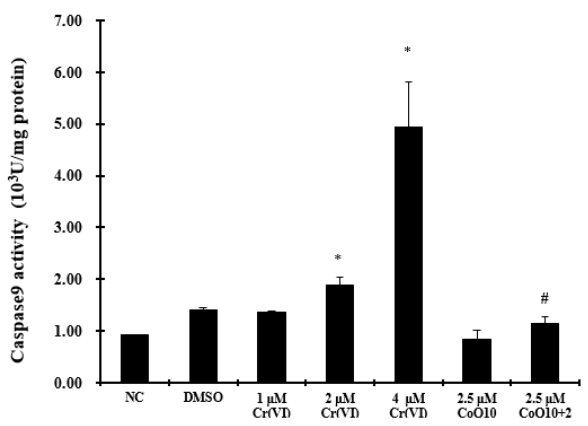

$\mathrm{D}$

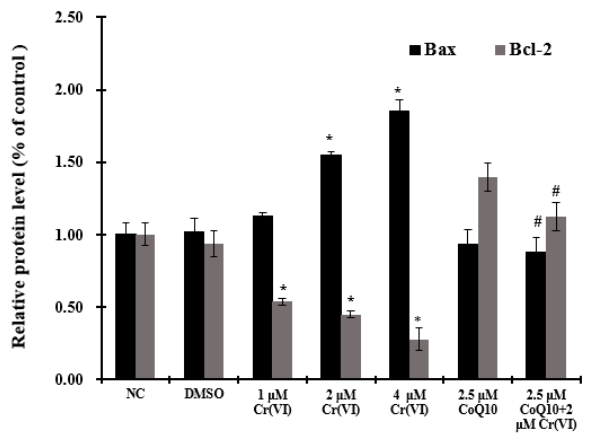

Figure 6. $\mathrm{Cr}(\mathrm{VI})$ induces caspase-3 and caspase-9 activation and unbalanced $\mathrm{Bcl}-2 /$ Bax expression in response to apoptotic stimuli, and CoQ10 counteracts these outcomes. Cells were treated with $\mathrm{Cr}(\mathrm{VI})$ $(0 \sim 4 \mu \mathrm{M})$ for $24 \mathrm{~h}$, with or without CoQ10 pretreatment for $2 \mathrm{~h}$. Caspase-3 (A) and -9 (B) activities were detected using a microplate reader; (C) The expression of Bcl-2 and Bax was measured by Western blotting and the relative protein levels were calculated by Image J software (D). The data are expressed as mean $\pm \mathrm{SD}(n=6) .{ }^{*} p<0.05$ compared with the control group; \# $p<0.05$ compared with the $2 \mu \mathrm{M}$ $\mathrm{Cr}(\mathrm{VI})$ treatment group.

2.8. Cr(VI) Induces L-02 Hepatocyte Apoptosis in a Concentration-Dependent Manner, and CoQ10 Might Reduce the Rate of Apoptosis

To measure the effects of CoQ10 on programmed cell death after $\mathrm{Cr}(\mathrm{VI})$ exposure, we analyzed cell apoptosis using the Annexin V-FITC and propidium iodide (PI) double staining methods after incubation for $30 \mathrm{~min}$. As shown in Figure 7A,B, $24 \mathrm{~h}$ exposure of $\mathrm{Cr}(\mathrm{VI})$ increased the early and late apoptotic populations in L-02 hepatocytes. Approximately $5.95 \%-48.46 \%$ of the cell population expressed high FITC and low PI signals, which are indicative of apoptotic cells, following treatment with up to $4 \mu \mathrm{M} \mathrm{Cr}(\mathrm{VI})$. Pretreatment with CoQ10 attenuated the $\mathrm{Cr}(\mathrm{VI})$-induced increase in Annexin V-positively stained cells. The protective effect of CoQ10 on $\mathrm{Cr}(\mathrm{VI})$-induced apoptosis was $15.28 \%$ $(p<0.05)$, indicating that $\mathrm{CoQ} 10$ can attenuate $\mathrm{Cr}(\mathrm{VI})$-induced apoptosis.

$\mathbf{A}$

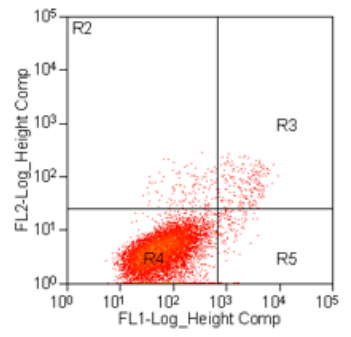

control

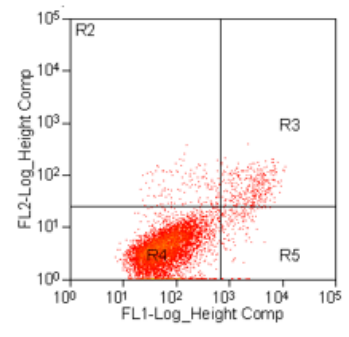

DMso

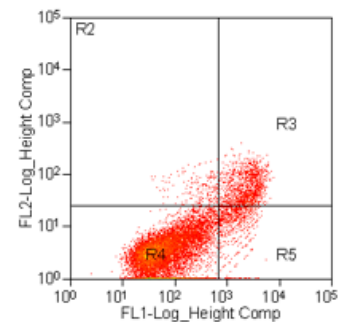

$1 \mu \mathrm{M} \mathrm{Cr}(\mathrm{VI})$

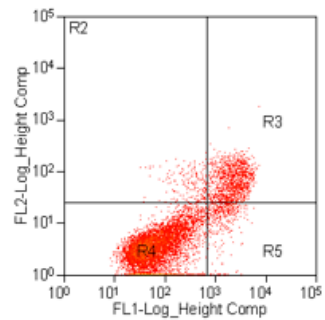

$2 \mu \mathrm{M} \mathrm{Cr}(\mathrm{VI})$

Figure 7. Cont. 


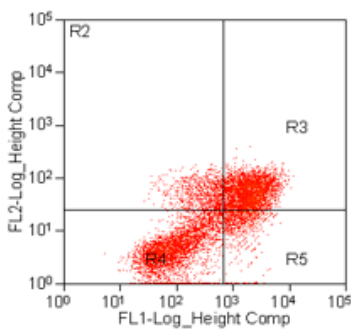

$4 \mu \mathrm{M} \mathrm{Cr}(\mathrm{VI})$

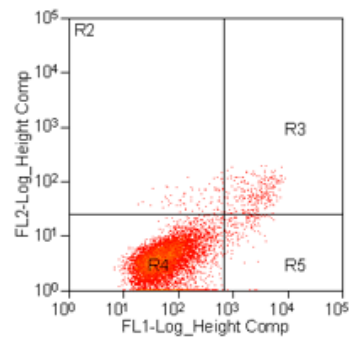

$2.5 \mu \mathrm{M}$ CoQ10

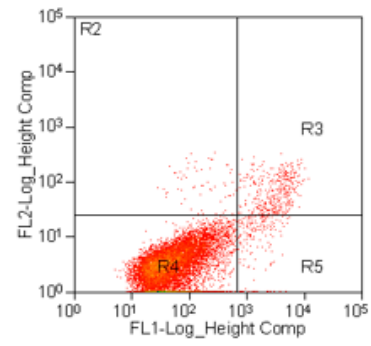

$2.5 \mu \mathrm{M}$ CoQ10+ $2 \mu \mathrm{M} \mathrm{Cr}(\mathrm{VI})$

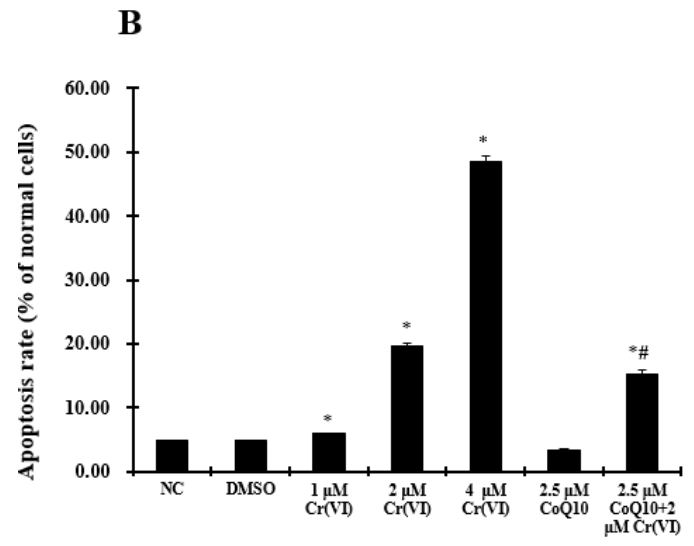

Figure 7. Cr(VI) induces apoptosis in L-02 hepatocytes, and CoQ10 antagonizes apoptosis. (A) Cells were stained with Annexin V-FITC/PI and analyzed by flow cytometry. Both early apoptotic and late apoptotic cells were assessed in the cell death determinations. The experiments were repeated three times; (B) Quantification of apoptotic cells. Data were obtained from flow cytometry assays and were expressed as mean $\pm \mathrm{SD}(n=6) .{ }^{*} p<0.05$ compared with the control group; $\# p<0.05$ compared with the $2 \mu \mathrm{M} \mathrm{Cr}(\mathrm{VI})$ treatment group.

\section{Discussion}

In the present study, we demonstrated that $\mathrm{Cr}(\mathrm{VI})$ decreased the level of endogenous CoQ10 by disturbing the CoQ10 synthesis pathway, and that the pretreatment with CoQ10 maintained the level of endogenous CoQ10. These findings led us to investigate the role of CoQ10 in the mechanism of $\mathrm{Cr}(\mathrm{VI})$-induced hepatotoxicity and its possible role as a hepatoprotective agent against $\mathrm{Cr}(\mathrm{VI})$-induced hepatocyte damage.

In order to achieve these goals, we examined the genes involved both directly and indirectly in the CoQ10 biosynthetic pathway. $\mathrm{Cr}(\mathrm{VI})$ changed the expression of many genes, including ETFDH, which exhibited the strongest downregulation. ETFDH is indirectly involved in the biosynthesis of CoQ10 and encodes a component of the electron-transfer system in mitochondria. Gempel et al. reported that mutations in the ETFDH gene cause pure myopathy, as evidenced in seven patients from five different families with severely decreased activities of respiratory chain complexes I and II + III and CoQ10 deficiency [30]. We also previously demonstrated that $\mathrm{Cr}(\mathrm{VI})$ induces mitochondrial dysfunction by disturbing electron transport and inhibiting the respiratory chain complexes. As a link to our present study, we tentatively propose that $\mathrm{Cr}(\mathrm{VI})$ may cause secondary deficiency of CoQ10 in L-02 hepatocytes, resulting in mitochondrial dysfunction and cell apoptosis. This result provides a new perspective on the mechanism of $\mathrm{Cr}(\mathrm{VI})$-induced hepatotoxicity.

In addition, $\mathrm{Cr}(\mathrm{VI})$ downregulated the expression of PDSS2, COQ5, and COQ9, which are directly involved in the CoQ10 biosynthesis pathway. Defects in these genes are a cause of CoQ10 deficiency [31]. COQ5 catalyzes the only C-methylation step in the CoQ10 biosynthesis pathway in yeast. Chen et al. demonstrated that an uncoupling chemical in CoQ10 dose deficiency downregulates 
the mature form of COQ5. They also showed that knockdown of the COQ5 gene reduces CoQ10 levels, indicating that COQ5 plays a critical role in the biosynthesis of CoQ10 [32]. In the present study, $\mathrm{Cr}(\mathrm{VI})$ suppressed COQ5 gene expression, but not strongly. It is possible that $\mathrm{Cr}(\mathrm{VI})$ induced ETFDH inhibition, causing mitochondrial dysfunction to disturb the expression of genes in CoQ10 biosynthesis. This is supported by Hsiu-Chuan's study, which reported the suppressive effect of FCCP on COQ5 levels in association with decreased mitochondrial membrane potential, mitochondrial ATP production, and CoQ10 levels [33]. Interestingly, $A D C K 3$ was upregulated after exposure to $\mathrm{Cr}(\mathrm{VI})$, although not significantly. $A D C K 3$ is required for the biosynthesis of CoQ10, and mutation of $A D C K 3$ has been associated with CoQ10 deficiency in humans [34]. ADCK3 also functions in an electron-transferring membrane protein complex in the respiratory chain. Tumor suppressor p53 can induce $A D C K 3$ expression, and in response to DNA damage, inhibition of $A D C K 3$ expression partially suppresses p53-induced apoptosis [35]. We believe that CoQ10 maintains homeostasis only when gene expression is maintained at normal levels. However, little is currently known about the regulation of CoQ10 gene expression. Here, we present preliminary data that mitochondrial CoQ10 deficiency may represent a potential biomarker of $\mathrm{Cr}(\mathrm{VI})$ toxicity. However, to better understand the mechanism of $\mathrm{Cr}(\mathrm{VI})$-induced CoQ10 deficiency, more robust evidence is needed.

Mitochondrial loss has been indicated to play a prominent role in mitochondrial dysfunction. Our results showed that $\mathrm{Cr}(\mathrm{VI})$ exposure led to mitochondrial loss in hepatocytes, as reflected by a decrease in the mitochondrial mass, mtDNA copy number, and inhibition of expression of components of the mitochondrial respiratory chain [36]. The observed $\mathrm{Cr}(\mathrm{VI})$-induced decrease in the level of mtDNA copy number supports a link between CoQ10 deficiency and mtDNA depletion [37,38]. Moreover, mtDNA is vulnerable to ROS due to the lack of protection from histones and a self-repair mechanism. Our results also sowed $\mathrm{Cr}(\mathrm{VI})$-induced CoQ10 deficiency and ROS accumulation. It is reported that CoQ10 deficiency may cause mitochondrial dysfunction, thus triggering ROS generation. The capability of ROS scavenging is weakened, possibly further aggravating ROS accumulation due to CoQ10 deficiency [39]. Supplementation with CoQ10 could increase the mitochondrial mass, mtDNA copy number, and mitochondrial electron transport chain activity, as demonstrated by our study and Duberley's research [40]. Previous investigations have also shown that CoQ10 protects against neuron apoptosis induced by iron by reducing ROS accumulation and inhibiting lipid peroxidation [41]. Consistent with previous studies, we found that pretreatment with CoQ10 eliminated excessive ROS and $\mathrm{O}_{2}{ }^{-}$, reduced lipid peroxidation, and maintained SOD content. SOD plays an important role in the protection of cell membranes against oxidative stress by catalyzing the dismutation of $\mathrm{O}_{2}{ }^{-}$to $\mathrm{O}_{2}$ and to the less reactive species $\mathrm{H}_{2} \mathrm{O}_{2}$ [42], corroborating the findings that CoQ10 plays a critical role in $\mathrm{Cr}(\mathrm{VI})$-induced mitochondrial dysfunction.

Mitochondria are the factory of ATP production via oxidative phosphorylation [43]. In return, the primary function of mitochondria and homeostasis are maintained by adequate ATP levels. CoQ10 is an essential cofactor of oxidative phosphorylation to permit ATP biosynthesis [44]. Our data indicated that $\mathrm{Cr}(\mathrm{VI})$ causes CoQ10 deficiency and markedly reduces cellular ATP. ATP production is also related to $\mathrm{Ca}^{2+}$ and $\mathrm{ROS}$ generation. Calcium overload has been proposed to play a crucial role in ROS generation [45], which could aggravate mitochondrial damage in hepatocytes. Furthermore, $\mathrm{Ca}^{2+}$ induces Cyt c release from mitochondria by enhancing Cyt c dislocation, competing for cardiolipin-binding sites in the mitochondrial inner membrane, or activating MPTP opening, resulting in the disturbance of electron transfer and the $\mathrm{Q}$ cycle. As a consequence, there is an upsurge in ROS accumulation [46]. Therefore, eliminating $\mathrm{Ca}^{2+}$ overload and ROS accumulation are conducive to promoting ATP synthesis and repairing damaged mitochondria. In this study, we have demonstrated that CoQ10 could attenuate $\mathrm{Cr}(\mathrm{VI})$-induced adverse effects by preventing $\mathrm{Ca}^{2+}$ overload and scavenging excessive ROS.

Apoptosis is an energy-consuming process that is regulated by the activation of caspases [47]. $\mathrm{Cr}(\mathrm{VI})$ induced the release of Cyt $\mathrm{c}$ from mitochondria, accompanied by activation of caspase-3 and 9, which are associated with significantly reduced Bcl-2 expression and enhanced Bax expression. 
Previous studies have confirmed that, after Cyt $\mathrm{c}$ is released from the mitochondrial intermembrane space into the cytosol, it forms a complex with Apaf- 1 and pro-caspase, thereby triggering caspase- 9 activation and the consequent initiation of the caspase cascade and induction of cell apoptosis [48]. In addition, cell apoptosis is regulated by the balance of pro- and anti- apoptotic proteins. It is generally believed that the anti-apoptotic protein Bcl- 2 counterbalances oxidative damage and maintains the structural and functional integrity of the mitochondrial membrane by preventing Cyt $\mathrm{c}$ release. The Bax protein exerts an important effect in cell apoptosis. High Bax expression levels and the formation of homo- or heterodimers with Bcl-2 lead to cell death [49]. We also saw that pretreatment with CoQ10 could block the release of Cyt c, inhibit the activation of caspase- 3 and caspase- 9 , and regulate the expression of Bcl-2/Bax to reach equilibrium and prevent subsequent apoptosis in L-02 hepatocytes. These results are compatible with the findings of other studies using CoQ10 against iron-induced neuronal toxicity [28], statin toxicity in hepatocytes [50], or ethanol-induced apoptosis in corneal fibroblasts [51].

As mentioned above, CoQ10 could alleviate $\mathrm{Cr}(\mathrm{VI})$-induced hepatotoxicity. However, the mechanism of the protective effects of CoQ10 is not fully understood. Possible reasons for the protective effects of $\mathrm{CoQ} 10$ in $\mathrm{Cr}(\mathrm{VI})$-induced toxicity include the fact that $\mathrm{Cr}(\mathrm{VI})$ is a water-soluble compound that can be easily reduced by water-soluble antioxidants [52]. Therefore, $\mathrm{Cr}(\mathrm{VI})$ might be reduced to $\mathrm{Cr}$ (III) before entering the cell when co-incubated with CoQ10. However, considering that $\mathrm{Cr}(\mathrm{VI})$ can dissolve in the medium, CoQ10, being a lipid-soluble quinone, may fail to interact with $\mathrm{Cr}(\mathrm{VI})$ outside the cell. On the other hand, since the cells were pretreated with CoQ10 for $2 \mathrm{~h}$ prior to exposure to $\mathrm{Cr}(\mathrm{VI})$, it is possible that CoQ10 may have entered the cell, and CoQ10 was distributed on membranes to block the opening of anion channels to prevent the entrance of $\mathrm{Cr}(\mathrm{VI})$ into the cell. This is supported by several studies showing that quinones modulate MPTP through a common binding site rather than through redox reactions [53,54]. This study also demonstrated that CoQ10 could decrease the MPTP opening degree to antagonize the mitochondrial toxicity induced by $\mathrm{Cr}(\mathrm{VI})$. Moreover, considering that exogenous CoQ10 enhanced the level of CoQ10 in mitochondria, we propose that the protective effect of CoQ10 might be associated with its role as a mobile electron transporter. CoQ10 can correct the disorder of electron transfer and improve the $\mathrm{Q}$ cycle, thus attenuating $\mathrm{Ca}^{2+}$ overload and Cyt $\mathrm{c}$ release. We have shown that CoQ10 can prevent cell apoptosis, but the results did not indicate how $\mathrm{CoQ} 10$ plays a protective role against $\mathrm{Cr}(\mathrm{VI})$-induced hepatotoxicity. The detoxification role of CoQ10 against $\mathrm{Cr}(\mathrm{VI})$-induced hepatotoxicity should be more comprehensively investigated.

\section{Materials and Methods}

\subsection{Materials}

Potassium dichromate $\left(\mathrm{K}_{2} \mathrm{Cr}_{2} \mathrm{Q}_{7}\right)$, coenzyme Q10, 3-(4,5-dimethylthiazol-2-yl)-2,5-diphenyltetrazolium bromide (MTT), and dimethyl sulfoxide (DMSO) were purchased from Sigma (St. Louis, MO, USA). RPMI-1640 culture medium, fetal bovine serum (FBS), trypsin, and penicillin-streptomycin were provided by Dingguo Changsheng Biotechnology Co. LTD (Beijing, China). All solvents and chemicals were analytical grade.

\subsection{Cell Culture}

The normal liver L-02 cell line (Type Culture Collection of the Chinese Academy of Sciences, Shanghai, China) was derived from adult human normal liver, immortalized by stable transfection with the hTERT [55], and was reported to be liver-specific [56]. L-02 hepatocytes were maintained in 1640 RPMI medium containing $10 \%$ fetal bovine serum and a $1 \%$ mixture of penicillin and streptomycin in a $5 \% \mathrm{CO}_{2}$ humidified atmosphere at $37^{\circ} \mathrm{C}$. The medium was changed every two days, and the cells were passaged using trypsin. 


\subsection{Treatment of Cells with $\mathrm{Cr}(\mathrm{VI})$ and $\mathrm{CoQ} 10$}

Cells were treated with a final concentration of $1-4 \mu \mathrm{M} \mathrm{K}_{2} \mathrm{Cr}_{2} \mathrm{Q}_{7}$ for $24 \mathrm{~h}$ in a complete medium. Cells were pretreated for $2 \mathrm{~h}$ prior to $\mathrm{K}_{2} \mathrm{Cr}_{2} \mathrm{Q}_{7}$ exposure and were co-treated for the $24-\mathrm{h} \mathrm{K}_{2} \mathrm{Cr}_{2} \mathrm{Q}_{7}$ exposure period at a final concentration of $2.5 \mu \mathrm{M}$ CoQ10. Control samples were exposed to an equivalent concentration of DMSO as the solvent control.

\subsection{Cell Viability Assay}

MTT was used to evaluate cell viability. Cells were seeded in 96-well plates $\left(1 \times 10^{4} /\right.$ well $)$ and cultured in the presence of $0,0.5,1,2,4$, or $8 \mu \mathrm{M} \mathrm{Cr}(\mathrm{VI})$ or $0,1.25,2.5,5,10$, or $20 \mu \mathrm{M}$ CoQ10 for $24 \mathrm{~h}$. After $24 \mathrm{~h}$ of incubation, $10 \mu \mathrm{L}$ of MTT solution (stock solution of $5 \mathrm{mg} / \mathrm{mL}$ in PBS) was added to each well of the 96-well plates, and the plates were incubated for an additional $4 \mathrm{~h}$ at $37^{\circ} \mathrm{C}$. The MTT-reducing activity of the cells was measured by treatment with DMSO prior to reading at $490 \mathrm{~nm}$ with an automatic microplate reader.

\subsection{Preparation of Mitochondria}

The treated cells were washed with PBS and then centrifuged at $600 \mathrm{~g}$ for $5 \mathrm{~min}$. The supernatant was discarded, and the pellets were suspended in ice-cold lysis buffer $(250 \mathrm{mM}$ sucrose, $20 \mathrm{mM}$ $N$-(2-hydroxyethy)piperazine- $N^{\prime}$-(2-ethanesulfonic acid (HEPES), pH 7.4, $10 \mathrm{mM} \mathrm{KCl}, 1.5 \mathrm{mM} \mathrm{MgCl}$, $1 \mathrm{mM}$ each of EGTA, EDTA, DTT, and PMSF, and $10 \mu \mathrm{g} / \mathrm{mL}$ each of leupeptin, aprotinin, and pepstatin A) and incubated for $20 \mathrm{~min}$. The cells were homogenized up and down 20 times, on ice, at 1000 r.p.m., transferred to a new tube, and centrifuged at $600 \times g$ for $10 \mathrm{~min}$ at $4{ }^{\circ} \mathrm{C}$ The supernatant was then centrifuged at $12,000 \times \mathrm{g}$ for $10 \mathrm{~min}$ at $4{ }^{\circ} \mathrm{C}$. Afterwards, the supernatants were collected and centrifuged at $12,000 \times g$ for $15 \mathrm{~min}$ at $4{ }^{\circ} \mathrm{C}$ for preparation of the cytosolic fraction. The precipitated pellets were resuspended in the lysis buffer and were used as the mitochondrial fraction after centrifugation at $12,000 \times g$ for $10 \mathrm{~min}$ [57].

\subsection{Extraction and Quantification of CoQ10}

Extraction was performed as described previously. Briefly, $250 \mu \mathrm{L}$ of samples and $750 \mu \mathrm{L}$ of hexane:ethanol $(5: 2, v / v)$ were mixed together for $1 \mathrm{~min}$ using a vortex mixer. The mixture was centrifuged for $3 \mathrm{~min}$ at $4000 \times \mathrm{g}$, and $450 \mu \mathrm{L}$ of the hexane layer was collected, dried under a stream of nitrogen, and dissolved in $100 \mu \mathrm{L}$ of ethanol $(1: 1, v / v)$ [58]. Quantification of CoQ10 was performed by HPLC according to Lass and Sohal [59]. A 10- $\mu \mathrm{L}$ aliquot of the extract was chromatographed on a reverse-phase C180 HPLC column (150 mm $\times 4.6 \mathrm{~mm}, 5 \mu \mathrm{M}$; Thermo Hypersil), using a mobile phase consisting of ethanol: methanol $(1: 1, v / v)$ at a flow rate of $0.8 \mathrm{~mL} / \mathrm{min}$. The eluent was monitored with a UV detector at $275 \mathrm{~nm}$.

\subsection{Gene Chip ANALYSIS}

Total RNA was isolated using Trigo (Sigma), and first-strand cDNA was synthesized using RevertAid M-MuL V Reverse Transcriptase (Thermo, Waltham, MA, USA). A Genechip 30 IVT Express Kit was used to synthesize double-stranded cDNA for in vitro transcription (IVT, standard Affymetrix procedure, Santa Clara, CA, USA). During the synthesis of the amplified RNA (aRNA), a biotinylated nucleotide analog was incorporated as a label for the message, and the aRNA was purified with magnetic beads. A 15- $\mu$ g quantity of aRNA was fragmented with a fragmentation buffer according to the manufacturer's instructions. Next, $15 \mu \mathrm{g}$ of fragmented aRNA were hybridized with Affymetrix Human Genome U133 plus 2.0 arrays, according to the manufacturer's instructions. The chips were heated in a GeneChip Hybridization Oven- 645 for $16 \mathrm{~h}$ at $60 \mathrm{rpm}$ and $45^{\circ} \mathrm{C}$. The chips were washed and stained using a Genechip Fluidics Station-450 with the Affymetrix HWS kit. Chip scanning was performed with an Affymetrix Gene-Chip Scanner-3000-7G, and the normalized data were extracted using Affymetrix GCOS software (1.0, Santa Clara, CA, USA). The normalized spot intensities were 
transformed to gene expression log 2 ratios, and comparisons between control and treated groups were conducted using a $t$-test. A $p$-value $\leq 0.05$ and a fold change value $\geq 2$ indicated statistically significant regulation. A two-fold change was indicated at $\log 2$ (Ratio) $\geq 1.0$ or $\log 2$ (Ratio) $\leq-1$.

\subsection{Real-Time PCR}

Total RNA was isolated using Trigo (Sigma), and the first-strand cDNA was synthesized using RevertAid M-MuL V Reverse Transcriptase (Thermo). The cDNA was amplified in 20- $\mu$ L reactions using SYBR premix Dye I (TAKARA BIO, Shiga, Japan) in a Thermal Cycler Dice Real-Time System (TAKARA BIO). The mRNA expression was normalized to the expression of the standard reference gene GAPDH. The primer sequences are shown in the Table 2.

Table 2. Primer sequences.

\begin{tabular}{ccc}
\hline Target & Forward Primer $\left(5^{\prime} \rightarrow \mathbf{3}^{\prime}\right)$ & Reverse Primer $\left(5^{\prime} \rightarrow \mathbf{3}^{\prime}\right)$ \\
\hline mtDNA & CAAACCTACGCCAAAATCCA & GAAATGAATGAGCCTACAGA \\
GAPDH & TGACAACAGCCTCAAGAT & GAGTCCTTCCACGATACC \\
\hline
\end{tabular}

\subsection{Determination of Reactive Oxygen Species (ROS)}

Cells were washed three times with a serum-free medium, and thereafter CellROX ${ }^{\circledR}$ Green Reagent (Thermo Fisher, Waltham, MA, USA) was added to the cells at $5 \mu \mathrm{M}$ final concentration, followed by incubation for $30 \mathrm{~min}$ at $37^{\circ} \mathrm{C}$. The cells were then washed twice with PBS and harvested. One hundred microliters of resuspended sample were added to 96-well plates, and ROS levels were assessed by fluorescence spectrophotometry with excitation at $485 \mathrm{~nm}$ and emission at $520 \mathrm{~nm}$. Cells on the coverslip were observed under a confocal microscope.

\subsection{Measurement of Superoxide Anion $\left(\mathrm{O}_{2}{ }^{-}\right)$}

The treated cells were incubated with the cellular $\mathrm{O}_{2}{ }^{-}$-sensitive fluorescent indicator dihydroethidium (DHE) at a final concentration of $5 \mu \mathrm{M}$ for $30 \mathrm{~min}$ at $37^{\circ} \mathrm{C}$, and protected from light. They were washed three times with PBS, collected, resuspended in $2 \mathrm{~mL}$ of PBS, and finally examined by fluorescence spectrophotometry with excitation at $535 \mathrm{~nm}$ and emission at $610 \mathrm{~nm}$.

\subsection{Evaluation of Methane Dicarboxylic Aldehyde (MDA) and Superoxide Dismutase (SOD) Levels}

MDA levels were determined using the trace MDA detection kit and a microplate reader at $530 \mathrm{~nm}$. SOD levels were measured using the total superoxide dismutase activity assay, which involves the inhibition of superoxide-induced chromogen chemiluminescence by SOD, according to the manufacturer's instructions. The absorbance of the wells was read using a microplate reader at a primary wavelength of $550 \mathrm{~nm}$.

\subsection{Measurement of the Mitochondrial Mass}

The mitochondrial mass was evaluated using the fluorescent probe 10- $N$-nonyl acridine orange (NAO) as previously described [30]. Treated cells were incubated in a medium containing $5 \mu \mathrm{M}$ NAO for $30 \mathrm{~min}$ at $37^{\circ} \mathrm{C}$ and protected from light. The NAO fluorescence intensity was determined using a microplate reader (Gemini EM, Molecular Devices, Sunnyvale, CA, USA). The emission and excitation wavelengths were 530 and $485 \mathrm{~nm}$, respectively.

\subsection{Measurement of the Mitochondrial Transmembrane Potential (MMP, $\Delta \psi m$ ) in Cells}

The cells were loaded with JC- 1 for $20 \mathrm{~min}$ at $37^{\circ} \mathrm{C}$. Depolarization of $\Delta \psi \mathrm{m}$ was assessed by measuring the fluorescence intensities at excitation and emission wavelengths of 490 and $539 \mathrm{~nm}$, respectively, to measure JC-1 monomers. An excitation wavelength of $525 \mathrm{~nm}$ and an emission 
wavelength of $590 \mathrm{~nm}$ were used to measure JC-1 aggregates using a fluorescence microplate reader. During the measurements, the cells were maintained at $4{ }^{\circ} \mathrm{C}$ and protected from light. All fluorescence measurements were corrected by autofluorescence, which was determined using cells not loaded with JC-1.

\subsection{Measurement of the MPTP Opening Degree}

The cells were washed three times with PBS, and calcein-AM was added, followed by incubation for $20 \mathrm{~min}$ at $37^{\circ} \mathrm{C}$. Next, the cells were washed twice with GENMED cleaning liquid, harvested, resuspended in a cleaning liquid, and finally examined by fluorescence spectrophotometry with excitation at $488 \mathrm{~nm}$ and emission at $505 \mathrm{~nm}$.

\subsection{Measurement of Intracellular ATP Levels}

The level of ATP was examined using the ATP assay kit (S0026, Beyotime, Shanghai, China), which utilized the catalysis of firefly luciferase to generate fluorescence requiring ATP to develop an ATP quantified method. The measurement was performed following the manufacturer's instructions. The absorbance was detected using a Luminometer.

\subsection{Measurement of the Cellular Calcium Concentration $\left(\mathrm{Ca}^{2+}\right)$}

Cultured cells were incubated with the cellular $\mathrm{Ca}^{2+}$-sensitive fluorescence indicator Fluo-3AM at a final concentration of $2.5 \mu \mathrm{M}$ for $30 \mathrm{~min}$ at $37^{\circ} \mathrm{C}$ and protected from light. The cells were subsequently washed three times with PBS, collected, and resuspended in $2 \mathrm{~mL}$ of PBS for posterior examination by fluorescence spectrophotometry with excitation at $488 \mathrm{~nm}$ and emission at $525 \mathrm{~nm}$.

\subsection{Caspase Activity Assay}

Caspase levels were measured with caspase- 3 and caspase-9 activity assay kits according to the manufacturer's instructions (Beyotime). The absorbance was measured on a microplate reader at $405 \mathrm{~nm}$, and the caspase activities were subsequently calculated based on the absorbance.

\subsection{Western Blot Analysis}

For Western blot analysis, cytosolic and mitochondrial fractions were prepared as reported previously. Samples containing an equal amount of concentrated proteins were separated on $10 \%$ gradient SDS-polyacrylamide gel and transferred to a polyvinylidene difluoride membrane by electroblotting for $90 \mathrm{~min}$ at $100 \mathrm{~V}$ and $4{ }^{\circ} \mathrm{C}$. Non-specific membrane binding sites were blocked with blocking solution (PBS, 0.5\% Tween-20, pH 7.4), containing 5\% non-fat dry milk for $1 \mathrm{~h}$ at $4{ }^{\circ} \mathrm{C}$. The membrane was incubated with primary mouse anti-Cyt c monoclonal antibody (Abcam, Cambridge, UK) diluted 1:1500 or goat anti-rabbit Bcl-2 (1:500, Santa Cruz, Santa Cruz, CA, USA) and Bax antibody (1:500, Santa Cruz) in blocking solution overnight at $4{ }^{\circ} \mathrm{C}$. The membrane was washed thoroughly with PBS-T and then incubated for $1 \mathrm{~h}$ with horseradish peroxidase-conjugated anti-mouse (1:4000; Santa Cruz) or anti-rabbit IgG antibody (1:6000; Santa Cruz) in blocking solution, detected by chemiluminescence reagent plus, and exposed to film.

\subsection{Immunofluorescence}

Cyt $\mathrm{c}$ translocation from mitochondria to cytoplasm was analyzed by immunofluorescence. Treated cells were incubated with Mito-Tracker Red (Thermo Fisher) at $500 \mathrm{nM}$ for $45 \mathrm{~min}$, washed twice with PBS, and with $2 \%$ paraformaldehyde for $20 \mathrm{~min}$ at room temperature. The cells were blocked with blocking solution (1\% BSA, $0.15 \%$ saponin and $10 \%$ goat serum in PBS) for $30 \mathrm{~min}$ at room temperature, incubated with primary antibody specific for Cyt c $(1: 200)$ overnight at $4{ }^{\circ} \mathrm{C}$, and then incubated with secondary antibody for $1 \mathrm{~h}$ at room temperature. The cells were washed three 
times with PBS, and then the nuclei were stained with Hoechst for 5 min. Images were captured with a confocal microscope.

\subsection{FITC Annexin V/propidium Iodide (PI) Staining for Apoptotic Cells}

Cells were washed three times with PBS before suspension in binding buffer, and $10 \mu \mathrm{L}$ of Annexin V-FITC were mixed with $200 \mu \mathrm{L}$ of cell suspension containing $10^{6}$ cells. The cells were incubated at room temperature for $30 \mathrm{~min}$ and shielded from light. Then, $10 \mu \mathrm{L}$ of PI solution were added to the cells and they were incubated for $10 \mathrm{~min}$ on ice. The scatter parameters of the cells were analyzed using a flow cytometer. Usually, four cell populations are identified by the flow cytometer. The viable population is displayed in the lower-left quadrant; the early apoptotic population and late apoptotic population are presented in the lower-right quadrant and in the upper-right quadrant, respectively. Signals in the upper-left quadrant present a necrotic population.

\subsection{Protein Assay}

All protein assays in this study were measured using a Q5000 UV-Vis spectrophotometer (Quawell, Sunnyvale, CA, USA).

\subsection{Statistical Analysis}

All data were expressed as the group mean $\pm \mathrm{SD}$. Comparisons between control and treated groups were conducted using one-way ANOVA, as appropriate, followed by LSD. A value of $p<0.05$ was considered to indicate statistical significance. Statistical analysis of the data was performed using SPSS18.0. All experiments were performed three times.

\section{Conclusions}

In conclusion, we have demonstrated that $\mathrm{Cr}(\mathrm{VI})$ may induce mitochondrial CoQ10 deficiency by inhibiting the expression of genes involved in the CoQ10 biosynthesis pathway, and by subsequently causing oxidative stress, altering the mitochondrial network, and reducing mitochondrial biogenesis. CoQ10 exerts a potent protective effect against $\mathrm{Cr}(\mathrm{VI})$-induced apoptosis, reduces intracellular oxidative stress, inhibits mitochondrial depolarization, increases mitochondrial mass and the mtDNA copy number, decreases the degree of MPTP opening, ameliorates caspase activity, equilibrates Bcl-2/Bax expression, and antagonizes subsequent apoptosis. We conclude that $\mathrm{Cr}(\mathrm{VI})$-induced CoQ10 deficiency might be corrected by supplementation with CoQ10, which appears to stimulate mitochondrial biogenesis and prevent apoptosis. Thus, new perspectives on mitochondrial toxicity related to $\mathrm{Cr}(\mathrm{VI})$ exposure are suggested, and we provide new insights into therapeutic potentials and strategies for protecting hepatocytes against $\mathrm{Cr}(\mathrm{VI})$-induced oxidative stress and apoptosis.

Acknowledgments: This study was supported, in part, by a grant from the Chinese National Natural Science Foundation (No. 81172701), a Chinese Council Scholarship (201506370074) and the Graduate Student Innovation Project in Hunan Province of China (CX2016B057). The authors appreciate the assistance of their excellent colleagues with this study.

Author Contributions: Xiali Zhong and Caigao Zhong designed the experiments; Xiali Zhong, Xing Yi, Yujing Zhang, and Kaihua Liu performed the experiments; Xiali Zhong and Fang Xiao analyzed the data; Xiali Zhong wrote the manuscript; Rita de Cássia da Silveira e Sá and Caigao Zhong revised the manuscript.

Conflicts of Interest: The authors declare no conflict of interest.

\section{Abbreviations}

$\begin{array}{ll}\text { Cr(VI) } & \text { hexavalent chromium } \\ \text { CoQ10 } & \text { coenzyme Q10 } \\ \text { ROS } & \text { reactive oxygen species } \\ \text { MMP } & \text { mitochondrial membrane potential } \\ \text { Cyt c } & \text { cytochrome c }\end{array}$




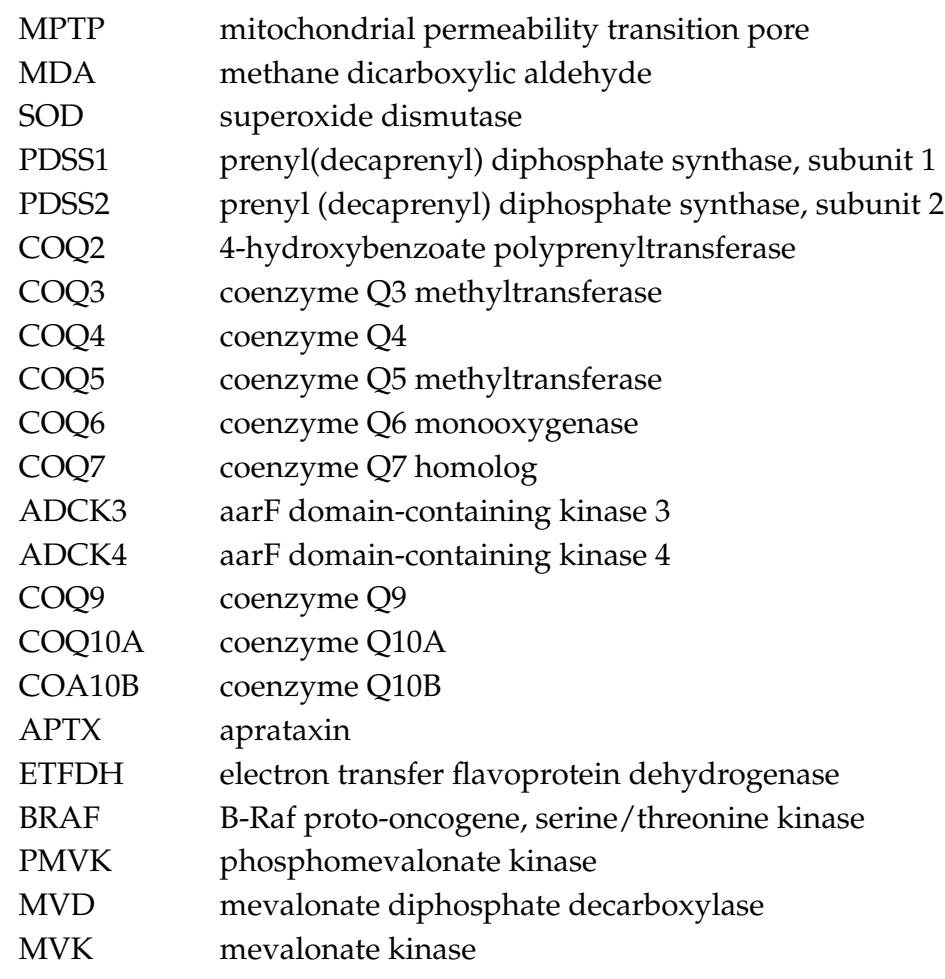

\section{References}

1. Krumschnabel, G.; Nawaz, M. Acute toxicity of hexavalent chromium in isolated teleost hepatocytes. Aquat. Toxicol. 2004, 70, 159-167. [CrossRef] [PubMed]

2. Thompson, C.M.; Kirman, C.R.; Proctor, D.M.; Haws, L.C.; Suh, M.; Hays, S.M.; Hixon, J.G.; Harris, M.A. A chronic oral reference dose for hexavalent chromium-induced intestinal cancer. J. Appl. Toxicol. 2014, 34, 525-536. [CrossRef] [PubMed]

3. Stout, M.D.; Herbert, R.A.; Kissling, G.E.; Collins, B.J.; Travlos, G.S.; Witt, K.L.; Melnick, R.L.; Abdo, K.M.; Malarkey, D.E.; Hooth, M.J. Hexavalent chromium is carcinogenic to F344/N rats and B6C3F1 mice after chronic oral exposure. Environ. Health Perspect. 2009, 117, 716-722. [CrossRef] [PubMed]

4. Costa, M. Toxicity and carcinogenicity of $\mathrm{Cr}(\mathrm{VI})$ in animal models and humans. Crit. Rev. Toxicol. 1997, 27, 431-442. [CrossRef] [PubMed]

5. Felter, S.P.; Dourson, M.L. Hexavalent chromium-contaminated soils: Options for risk assessment and risk management. Regul. Toxicol. Pharmacol. 1997, 25, 43-59. [CrossRef] [PubMed]

6. Megharaj, M.; Avudainayagam, S.; Naidu, R. Toxicity of hexavalent chromium and its reduction by bacteria isolated from soil contaminated with tannery waste. Curr. Microbial. 2003, 47, 51-54. [CrossRef] [PubMed]

7. Nudler, S.I.; Quinteros, F.A.; Miler, E.A.; Cabilla, J.P.; Ronchetti, S.A.; Duvilanski, B.H. Chromium VI administration induces oxidative stress in hypothalamus and anterior pituitary gland from male rats. Toxicol. Lett. 2009, 185, 187-192. [CrossRef] [PubMed]

8. Michie, C.A.; Hayhurst, M.; Knobel, G.J.; Stokol, J.M.; Hensley, B. Poisoning with a traditional remedy containing potassium dichromate. Hum. Exp. Toxicol. 1991, 10, 129-131. [CrossRef] [PubMed]

9. Collins, B.J.; Stout, M.D.; Levine, K.E.; Kissling, G.E.; Melnick, R.L.; Fennell, T.R.; Walden, R.; Abdo, K.; Pritchard, J.B.; Fernando, R.A.; et al. Exposure to hexavalent chromium resulted in significantly higher tissue chromium burden compared with trivalent chromium following similar oral doses to male F344/N rats and female B6C3F1 mice. Toxicol. Sci. 2010, 118, 368-379. [CrossRef] [PubMed]

10. Proctor, D.M.; Otani, J.M.; Finley, B.L.; Paustenbach, D.J.; Bland, J.A.; Speizer, N.; Sargent, E.V. Is hexavalent chromium carcinogenic via ingestion? A weight-of-evidence review. J. Toxicol. Environ. Health Part A 2002, 65, 701-746. [CrossRef] [PubMed] 
11. Xiao, F.; Feng, X.; Zeng, M.; Guan, L.; Hu, Q.; Zhong, C. Hexavalent chromium induces energy metabolism disturbance and p53-dependent cell cycle arrest via reactive oxygen species in L-02 hepatocytes. Mol. Cell. Biochem. 2012, 371, 65-76. [CrossRef] [PubMed]

12. Linos, A.; Petralias, A.; Christophi, C.A.; Christoforidou, E.; Kouroutou, P.; Stoltidis, M.; Veloudaki, A.; Tzala, E.; Makris, K.C.; Karagas, M.R. Oral ingestion of hexavalent chromium through drinking water and cancer mortality in an industrial area of Greece-An ecological study. Environ. Health 2011, 10, 50. [CrossRef] [PubMed]

13. Beaumont, J.J.; Sedman, R.M.; Reynolds, S.D.; Sherman, C.D.; Li, L.H.; Howd, R.A.; Sandy, M.S.; Zeise, L.; Alexeeff, G.V. Cancer mortality in a chinese population exposed to hexavalent chromium in drinking water. Epidemiology 2008, 19, 12-23. [CrossRef] [PubMed]

14. Yang, Y.; Liu, H.; Xiang, X.H.; Liu, F.Y. Outline of occupational chromium poisoning in china. Bull. Environ. Contam. Toxicol. 2013, 90, 742-749. [CrossRef] [PubMed]

15. Myers, J.M.; Antholine, W.E.; Myers, C.R. The intracellular redox stress caused by hexavalent chromium is selective for proteins that have key roles in cell survival and thiol redox control. Toxicology 2011, 281, 37-47. [CrossRef] [PubMed]

16. Wang, C.C.; Fang, K.M.; Yang, C.S.; Tzeng, S.F. Reactive oxygen species-induced cell death of rat primary astrocytes through mitochondria-mediated mechanism. J. Cell. Biochem. 2009, 107, 933-943. [CrossRef] [PubMed]

17. Banu, S.K.; Stanley, J.A.; Lee, J.; Stephen, S.D.; Arosh, J.A.; Hoyer, P.B.; Burghardt, R.C. Hexavalent chromium-induced apoptosis of granulosa cells involves selective sub-cellular translocation of Bcl-2 members, ERK1/2 and p53. Toxicol. Appl. Pharmacol. 2011, 251, 253-266. [CrossRef] [PubMed]

18. Marouani, N.; Tebourbi, O.; Mokni, M.; Yacoubi, M.T.; Sakly, M.; Benkhalifa, M.; Rhouma, K.B. Hexavalent chromium-induced apoptosis in rat uterus: Involvement of oxidative stress. Arch. Environ. Occup. Health 2015, 70, 189-195. [CrossRef] [PubMed]

19. McCarthy, S.; Somayajulu, M.; Sikorska, M.; Borowy-Borowski, H.; Pandey, S. Paraquat induces oxidative stress and neuronal cell death; neuroprotection by water-soluble coenzyme Q10. Toxicol. Appl. Pharmacol. 2004, 201, 21-31. [CrossRef] [PubMed]

20. Papucci, L.; Schiavone, N.; Witort, E.; Donnini, M.; Lapucci, A.; Tempestini, A.; Formigli, L.; Zecchi-Orlandini, S.; Orlandini, G.; Carella, G.; et al. Coenzyme Q10 prevents apoptosis by inhibiting mitochondrial depolarization independently of its free radical scavenging property. J. Biol. Chem. 2003, 278, 28220-28228. [CrossRef] [PubMed]

21. Doimo, M.; Desbats, M.A.; Cerqua, C.; Cassina, M.; Trevisson, E.; Salviati, L. Genetics of coenzyme Q10 deficiency. Mol. Syndromol. 2014, 5, 156-162. [CrossRef] [PubMed]

22. Kawamukai, M. Biosynthesis of coenzyme Q in eukaryotes. Biosci. Biotechnol. Biochem. 2015, 80, $23-33$. [CrossRef] [PubMed]

23. Quinzii, C.M.; Lopez, L.C.; Naini, A.; DiMauro, S.; Hirano, M. Human COQ10 deficiencies. BioFactors 2008, 32, 113-118. [CrossRef] [PubMed]

24. Ben-Meir, A.; Burstein, E.; Borrego-Alvarez, A.; Chong, J.; Wong, E.; Yavorska, T.; Naranian, T.; Chi, M.; Wang, Y.; Bentov, Y.; et al. Coenzyme Q10 restores oocyte mitochondrial function and fertility during reproductive aging. Aging Cell 2015, 14, 887-895. [CrossRef] [PubMed]

25. Quinzii, C.M.; Lopez, L.C.; Gilkerson, R.W.; Dorado, B.; Coku, J.; Naini, A.B.; Lagier-Tourenne, C.; Schuelke, M.; Salviati, L.; Carrozzo, R.; et al. Reactive oxygen species, oxidative stress, and cell death correlate with level of COQ10 deficiency. FASEB J. 2010, 24, 3733-3743. [CrossRef] [PubMed]

26. Quinzii, C.M.; Emmanuele, V.; Hirano, M. Clinical presentations of coenzyme Q10 deficiency syndrome. Mol. Syndromol. 2014, 5, 141-146. [CrossRef] [PubMed]

27. Potgieter, M.; Pretorius, E.; Pepper, M.S. Primary and secondary coenzyme Q10 deficiency: The role of therapeutic supplementation. Nutr. Rev. 2013, 71, 180-188. [CrossRef] [PubMed]

28. Kooncumchoo, P.; Sharma, S.; Porter, J.; Govitrapong, P.; Ebadi, M. Coenzyme Q10 provides neuroprotection in iron-induced apoptosis in dopaminergic neurons. J. Mol. Neurosci. 2006, 28, 125-141. [CrossRef]

29. Abdallah, G.M.; El-Sayed el, S.M.; Abo-Salem, O.M. Effect of lead toxicity on coenzyme Q levels in rat tissues. Food Chem. Toxicol. 2010, 48, 1753-1756. [CrossRef] [PubMed] 
30. Gempel, K.; Topaloglu, H.; Talim, B.; Schneiderat, P.; Schoser, B.G.H.; Hans, V.H.; Palmafy, B.; Kale, G.; Tokatli, A.; Quinzii, C.; et al. The myopathic form of coenzyme Q10 deficiency is caused by mutations in the electron-transferring-flavoprotein dehydrogenase (ETFDH) gene. Brain 2007, 130, 2037-2044. [CrossRef] [PubMed]

31. Acosta, M.J.; Fonseca, L.V.; Desbats, M.A.; Cerqua, C.; Zordan, R.; Trevisson, E.; Salviati, L. Coenzyme Q biosynthesis in health and disease. Biochim. Biophys. Acta. 2016, 1857, 1079-1085. [CrossRef] [PubMed]

32. Chen, S.W.; Liu, C.C.; Yen, H.C. Detection of suppressed maturation of the human COQ5 protein in the mitochondria following mitochondrial uncoupling by an antibody recognizing both precursor and mature forms of COQ5. Mitochondrion 2013, 13, 143-152. [CrossRef] [PubMed]

33. Yen, H.C.; Liu, Y.C.; Kan, C.C.; Wei, H.J.; Lee, S.H.; Wei, Y.H.; Feng, Y.H.; Chen, C.W.; Huang, C.C. Disruption of the human COQ5-containing protein complex is associated with diminished coenzyme Q10 levels under two different conditions of mitochondrial energy deficiency. Biochim. Biophys. Acta 2016, 1860, 1864-1876. [CrossRef] [PubMed]

34. Wheeler, B.; Jia, Z.C. Preparation and characterization of human ADCK3, a putative atypical kinase. Protein Expr. Purif. 2015, 108, 13-17. [CrossRef] [PubMed]

35. Liu, X.; Yang, J.; Zhang, Y.; Fang, Y.; Wang, F.; Wang, J.; Zheng, X.; Yang, J. A systematic study on drug-response associated genes using baseline gene expressions of the cancer cell line encyclopedia. Sci. Rep. 2016, 6, 22811. [CrossRef] [PubMed]

36. Xiao, F.; Li, Y.; Luo, L.; Xie, Y.; Zeng, M.; Wang, A.; Chen, H.; Zhong, C. Role of mitochondrial electron transport chain dysfunction in $\mathrm{Cr}(\mathrm{VI})$-induced cytotoxicity in L-02 hepatocytes. Cell. Physiol. Biochem. 2014, 33, 1013-1025. [CrossRef] [PubMed]

37. Montero, R.; Pineda, M.; Aracil, A.; Vilaseca, M.A.; Briones, P.; Sanchez-Alcazar, J.A.; Navas, P.; Artuch, R. Clinical, biochemical and molecular aspects of cerebellar ataxia and coenzyme Q10 deficiency. Cerebellum 2007, 6, 118-122. [CrossRef] [PubMed]

38. Lopez-Martin, J.M.; Salviati, L.; Trevisson, E.; Montini, G.; DiMauro, S.; Quinzii, C.; Hirano, M.; Rodriguez-Hernandez, A.; Cordero, M.D.; Sanchez-Alcazar, J.A.; et al. Missense mutation of the COQ2 gene causes defects of bioenergetics and de novo pyrimidine synthesis. Hum. Mol. Genet. 2007, 16, 1091-1097. [CrossRef] [PubMed]

39. Maguire, J.J.; Kagan, V.; Ackrell, B.A.; Serbinova, E.; Packer, L. Succinate-ubiquinone reductase linked recycling of $\alpha$-tocopherol in reconstituted systems and mitochondria: Requirement for reduced ubiquinone. Arch. Biochem. Biophys. 1992, 292, 47-53. [CrossRef]

40. Duberley, K.E.; Heales, S.J.R.; Abramov, A.Y.; Chalasani, A.; Land, J.M.; Rahman, S.; Hargreaves, I.P. Effect of coenzyme Q10 supplementation on mitochondrial electron transport chain activity and mitochondrial oxidative stress in coenzyme Q10 deficient human neuronal cells. Int. J. Biochem. Cell Biol. 2014, 50, 60-63. [CrossRef] [PubMed]

41. Garrido-Maraver, J.; Cordero, M.D.; Oropesa-Avila, M.; Fernandez Vega, A.; de la Mata, M.; Delgado Pavon, A.; de Miguel, M.; Perez Calero, C.; Villanueva Paz, M.; Cotan, D.; et al. Coenzyme Q10 therapy. Mol. Syndromol. 2014, 5, 187-197. [CrossRef] [PubMed]

42. Garcia-Sevillano, M.A.; Garcia-Barrera, T.; Navarro, F.; Gomez-Ariza, J.L. Absolute quantification of superoxide dismutase in cytosol and mitochondria of mice hepatic cells exposed to mercury by a novel metallomic approach. Anal. Chim. Acta 2014, 842, 42-50. [CrossRef] [PubMed]

43. Gong, L.L.; Wang, Z.H.; Li, G.R.; Liu, L.H. Protective effects of akebia saponin D against rotenone-induced hepatic mitochondria dysfunction. J. Pharmacol. Sci. 2014, 126, 243-252. [CrossRef] [PubMed]

44. Sohal, R.S.; Forster, M.J. Coenzyme Q, oxidative stress and aging. Mitochondrion 2007, 7, S103-S111. [CrossRef] [PubMed]

45. Kovac, S.; Domijan, A.M.; Walker, M.C.; Abramov, A.Y. Seizure activity results in calcium- and mitochondria-independent ROS production via NADPH and xanthine oxidase activation. Cell Death Dis. 2014, 5, e1442. [CrossRef] [PubMed]

46. Peng, T.I.; Jou, M.J. Oxidative stress caused by mitochondrial calcium overload. Ann. N. Y. Acad. Sci. 2010, 1201, 183-188. [CrossRef] [PubMed]

47. Richter, C.; Schweizer, M.; Cossarizza, A.; Franceschi, C. Control of apoptosis by the cellular ATP level. FEBS Lett. 1996, 378, 107-110. [CrossRef] 
48. Petronilli, V.; Penzo, D.; Scorrano, L.; Bernardi, P.; di Lisa, F. The mitochondrial permeability transition, release of cytochrome $\mathrm{C}$ and cell death. Correlation with the duration of pore openings in situ. J. Biol. Chem. 2001, 276, 12030-12034. [CrossRef] [PubMed]

49. Liu, G.; Wang, T.; Wang, T.; Song, J.; Zhou, Z. Effects of apoptosis-related proteins caspase-3, Bax and Bcl-2 on cerebral ischemia rats. Biomed. Rep. 2013, 1, 861-867. [CrossRef] [PubMed]

50. Eghbal, M.A.; Abdoli, N.; Azarmi, Y. Efficiency of hepatocyte pretreatment with coenzyme Q10 against statin toxicity. Arh. Hig. Rada Toksikol. 2014, 65, 101-108. [CrossRef] [PubMed]

51. Chen, C.C.; Liou, S.W.; Chen, C.C.; Chen, W.C.; Hu, F.R.; Wang, I.J.; Lin, S.J. Coenzyme Q10 reduces ethanol-induced apoptosis in corneal fibroblasts. PLoS ONE 2011, 6, e19111. [CrossRef] [PubMed]

52. Xu, X.R.; Li, H.B.; Gu, J.D.; Li, X.Y. Kinetics of the reduction of chromium VI by vitamin C. Environ. Toxicol. Chem. 2005, 24, 1310-1314. [CrossRef] [PubMed]

53. Turunen, M.; Olsson, J.; Dallner, G. Metabolism and function of coenzyme Q. Biochim. Biophys. Acta Biomembr. 2004, 1660, 171-199. [CrossRef]

54. Fontaine, E.; Bernardi, P. Progress on the mitochondrial permeability transition pore: Regulation by complex I and ubiquinone analogs. J. Bioenerg. Biomembr. 1999, 31, 335-345. [CrossRef] [PubMed]

55. Zhang, W.Y.; Cai, N.; Ye, L.H.; Zhang, X.D. Transformation of human liver L-02 cells mediated by stable HBX transfection. Acta Pharmacol. Sin. 2009, 30, 1153-1161. [CrossRef] [PubMed]

56. Ding, Z.B.; Shi, Y.H.; Zhou, J.; Qiu, S.J.; Xu, Y.; Dai, Z.; Shi, G.M.; Wang, X.Y.; Ke, A.W.; Wu, B.; et al. Association of autophagy defect with a malignant phenotype and poor prognosis of hepatocellular carcinoma. Cancer Res. 2008, 68, 9167-9175. [CrossRef] [PubMed]

57. Frezza, C.; Cipolat, S.; Scorrano, L. Organelle isolation: Functional mitochondria from mouse liver, muscle and cultured fibroblasts. Nat. Protoc. 2007, 2, 287-295. [CrossRef] [PubMed]

58. Turkowicz, M.J.; Karpinska, J. Analytical problems with the determination of coenzyme Q10 in biological samples. BioFactors 2013, 39, 176-185. [CrossRef] [PubMed]

59. Lass, A.; Sohal, R.S. Electron transport-linked ubiquinone-dependent recycling of $\alpha$-tocopherol inhibits autooxidation of mitochondrial membranes. Arch. Biochem. Biophys. 1998, 352, 229-236. [CrossRef] [PubMed]

(C) 2017 by the authors. Licensee MDPI, Basel, Switzerland. This article is an open access article distributed under the terms and conditions of the Creative Commons Attribution (CC BY) license (http:/ / creativecommons.org/licenses/by/4.0/). 